\title{
Mycotoxins and oxidative stress: where are we?
}

\author{
E.O. da Silva ${ }^{1}$, A.P.F.L. Bracarense ${ }^{1^{*}}$ and I.P. Oswald ${ }^{2 *}$ \\ ${ }^{1}$ Universidade Estadual de Londrina, Laboratory of Animal Pathology, Campus Universitário, Rodovia Celso Garcia Cid, \\ Km 380, Londrina, Paraná 86051-990, Brazil; ${ }^{2}$ Université de Toulouse, Toxalim, Research Center in Food Toxicology, \\ INRA, UMR 1331 ENVT, INP-PURPAN, 31076 Toulouse, France; ana.bracarense@pq.cnpq.br; isabelle.oswald@inra.fr
}

Received: 2 November 2017 / Accepted: 11 December 2017

(c) 2018 Wageningen Academic Publishers

OPEN ACCESS CP) REVIEW ARTICLE

\begin{abstract}
Mycotoxins are the most common contaminants of food and feed worldwide and are considered an important risk factor for human and animal health. Oxidative stress occurs in cells when the concentration of reactive oxygen species exceeds the cell's antioxidant capacity. Oxidative stress causes DNA damage, enhances lipid peroxidation, protein damage and cell death. This review addresses the toxicity of the major mycotoxins, especially aflatoxin $B_{1}$, deoxynivalenol, nivalenol, $\mathrm{T}-2$ toxin, fumonisin $\mathrm{B}_{1}$, ochratoxin, patulin and zearalenone, in relation to oxidative stress. It summarises the data associated with oxidative stress as a plausible mechanism for mycotoxin-induced toxicity. Given the contamination caused by mycotoxins worldwide, the protective effects of a variety of natural compounds due to their antioxidant capacities have been evaluated. We review data on the ability of vitamins, flavonoids, crocin, curcumin, green tea, lycopene, phytic acid, L-carnitine, melatonin, minerals and mixtures of anti-oxidants to mitigate the toxic effect of mycotoxins associated with oxidative stress.
\end{abstract}

Keywords: antioxidants, mycotoxins, oxidative stress.

\section{Introduction}

Mycotoxins are secondary fungal metabolites often found as contaminants in agricultural commodities all over the world and pose a risk for human and animal health (Bennett and Klich, 2003; Wu et al., 2014a). More than 400 different mycotoxins have been isolated and chemically characterised. Those of major medical and agricultural concern are aflatoxins, fumonisins, ochratoxins, trichothecenes, zearalenone (ZEA) and patulin (PAT) (Wu et al., 2014a).

The molecular mechanisms behind the toxic effects of the major mycotoxins are established and oxidative stress and the generation of free radicals have been shown to be implicated in mycotoxin toxicity (Adhikari et al., 2017; Wang et al., 2016). Indeed, the imbalance between free radicals and the antioxidant defence systems can cause chemical damage to DNA, proteins and lipids, as observed upon exposure to mycotoxins (Assi, 2017).
As human and animal exposure to mycotoxins is unavoidable, effective ways to mitigate their harmful impacts are required. Several studies have demonstrated the beneficial effects of antioxidant substances in the prevention and treatment of various diseases (Li et al., 2015). In this context, the use of natural antioxidants has been shown to mitigate and/or prevent the toxic effects of mycotoxins (Sorrenti et al., 2013).

The aims of this review are first to describe the cellular mechanisms involved in the physiological control and imbalance of free radical generation; second to summarise the toxic effects of the major mycotoxins associated with oxidative stress; and third, to present the main natural antioxidants used to mitigate the toxic effects of these mycotoxins. 


\section{Oxidative stress: physiological control and damage caused by overproduction of free radicals}

One consequence of aerobic conditions is activation of oxidative mechanisms and the subsequent generation of reactive oxygen species (ROS) (Droge, 2002). Cells have developed primary and secondary enzymatic systems to avoid ROS-induced damage (Valko et al., 2007). Superoxide dismutase (SOD), catalase (CAT), glutathione reductase (GR) and glutathione peroxidase (GPx) are characterised as primary antioxidant enzymes that trigger the breakdown of free radicals or combine toxic compounds with glutathione (GSH). The mechanisms of action of these enzymes are diverse. SOD breaks down the superoxide anion radical into $\mathrm{H}_{2} \mathrm{O}$ and $\mathrm{O}_{2}$, whereas CAT catalyses the decomposition of hydrogen peroxide $\left(\mathrm{H}_{2} \mathrm{O}_{2}\right)$ into water and oxygen. GPx reduces hydrogen peroxide to water and GR can regenerate GSH (Droge, 2002). By contrast, glutathione S-transferase (GST), a secondary detoxification enzyme, acts by binding ROS to GSH (Hayes and Strange, 1995) or by detoxifying lipid peroxides (Pickett and Lu, 1989).

Other mechanisms, including cysteine and GSH, are also involved in physiological control of ROS generation (Droge, 2002). GSH interacts with multiple antioxidant enzymes, modulating the action of GR, GPx and GST (a decrease in GSH content reduces enzymatic activity).

A control mechanism also exists for the expression of enzymes with antioxidant activity. Control is regulated by antioxidant response elements (AREs) that are activated by nuclear factor erythroid 2-related factor 2 (Nrf2) (Jin et al., 2014). Nrf2-ARE is considered to be an important signalling pathway associated with antioxidant activity. Cells subjected to oxidative stress induce Nrf2 translocation to the nucleus, thereby activating genes encoding antioxidant enzymes and detoxifying enzymes of phase II (e.g. SOD) through ARE binding. Interestingly, although high antioxidant induction is associated with Nrf2 when this pathway is activated by ROS, the response is limited because ROS also activates a cell death-signalling pathway (Jin et al., 2014; Valko et al., 2007).

Organelles such as peroxisomes and mitochondria provide membrane-limited compartments specialised in redox activities. Consumption of oxygen leads to the production of $\mathrm{H}_{2} \mathrm{O}_{2}$, which oxidises some molecules. Furthermore, these organelles contribute to metabolic functions as they contain CAT, an enzyme that decomposes the $\mathrm{H}_{2} \mathrm{O}_{2}$ and prevents intracellular accumulation of this compound (Valko et al., 2007). Cellular respiration in mitochondria creates one of the main superoxide production sites. During this process, ATP is produced by the electron transport chain and during energy transduction, free radical superoxide is formed, which has been associated with the cell pathophysiology in several diseases (Droge, 2002; Valko et al., 2007).

\section{Generation of oxidative stress, free radicals, and damage to DNA, proteins and lipids}

Cells in homeostasis may produce free radicals as a result of physiological reactions (cellular respiration, for example). A variety of exogenous factors can promote oxidative stress and overproduction of free radicals (Young and Woodside, 2001). Oxidative stress occurs in cells when the production of ROS, such as such as hydroxyl radical $(\mathrm{HO})$, perhydroxyl radical $\left(\mathrm{HOO}^{-}\right)$, superoxide anion $\left(\mathrm{O}_{2}^{-}\right)$ and reactive nitrogen species (RNS) including nitric oxide (NO), exceeds the antioxidant capacity of a cell (Valko et al., 2007). Changes in intracellular antioxidant systems or in the production of free radicals can result in oxidative stress (Halliwell and Whiteman, 2004). Increased ROS production alters and/or activates several intracellular mechanisms that promote oxidative damage to DNA, proteins and membrane lipids. Lipid peroxidation may also lead to cell death. The mechanisms involved in the induction of cell apoptosis caused by the generation of ROS include activation of $\mathrm{p} 53$, mitogen-activated protein kinases (MAPKs), caspases and changes in the Bcl-2/Bax expression (Farley et al., 2006).

Cells in homeostasis are maintained in a redox state through the association of the iron and copper redox couple. However, in a situation of oxidative stress, when superoxide is overproduced, the 'free iron' $\left(\mathrm{Fe}^{2+}\right)$ is released into the cytoplasm. This release considerably increases the oxidative stress, and leads to the generation of other reactive radicals through the Fenton reaction. In this reaction, $\mathrm{Fe}^{2+}$ and $\mathrm{H}_{2} \mathrm{O}_{2}$ generate one of the most harmful radicals, the reactive hydroxyl $\left(\mathrm{Fe}^{2+}+\mathrm{H}_{2} \mathrm{O}_{2} \rightarrow \mathrm{Fe}^{3+}+\cdot \mathrm{OH}^{+} \mathrm{OH}^{-}\right)$. Transition metal ions, mainly iron, have been implicated in the generation of highly reactive radicals leading to DNA and membrane damage. Cellular and organelle membranes are attractive targets for oxidation due to the polyunsaturated fatty acid residues of phospholipids (Birben et al., 2012). Secondary ROS metabolites can be produced, including endoperoxides (cyclisation reaction) and malondialdehyde (MDA), the toxic final product of lipid peroxidation, which is potentially mutagenic (Birben et al., 2012; Marnett, 1999).

The level of cytosolic calcium $\left(\mathrm{Ca}^{2+}\right)$ can be increased by ROS generation through an influx of extracellular $\mathrm{Ca}^{2+}$ or mobilisation of intracellular $\mathrm{Ca}^{2+}$ stores (Droge, 2002). This increase in the cytosolic $\mathrm{Ca}^{2+}$ level contributes to the activation of protein kinase $\mathrm{C}$ alpha and to the transcriptional induction of the activator protein 1 (AP1), c-Fos and c-Jun (Maki et al., 1992). MAPK signalling cascades are activated through a variety of membrane receptors (receptor tyrosine kinases, protein tyrosine kinases, receptors of cytokines and growth factors, and heterotrimeric G protein-coupled receptors) and are 
regulated by phosphorylation and dephosphorylation on serine and/or threonine residues (Droge, 2002). The association between oxidative stress and the generation of free radicals can activate the MAPK pathway, mainly c-Jun N-terminal kinase (JNK) and p38, resulting in cell apoptosis (Allen and Tressini, 2000).

Another important free reactive radical produced in biological systems is NO. NO is a normal cellular metabolite with different functions in cells including neurotransmission, maintaining vascular tone, defence, smooth muscle relaxation and immune regulation (Bergendi et al., 1999). Like with ROS, a nitrosative stress occurs following overproduction of RNS and disruption of the antioxidant system (Ridnour et al., 2004). The mechanisms of cell damage induced by nitrosative stress include changes in protein structure (through nitrosylation reactions) leading to inhibition of their function (Valko et al., 2007) and cell apoptosis. The induction of apoptosis by $\mathrm{NO}$ is associated with a decrease in the concentration of cardiolipin, an important component of the inner mitochondrial membrane. This molecule contributes to the optimal function of enzymatic systems involved in mitochondrial energy metabolism. A decrease in the cardiolipin level results in disruption of the electron transport chain, changes in mitochondria permeability and the release of cytochrome C into the cytosol (Droge, 2002). Furthermore, free radicals, such as superoxide anion and $\mathrm{NO}$, are produced by phagocytic cells during the respiratory burst occurring in the inflammatory process. Together, these radicals can react to produce the peroxynitrite anion $\left(\mathrm{ONOO}^{-}\right)$, a molecule that is a powerful oxidant and can cause DNA fragmentation and lipid oxidation.

The generation of free radicals can increase the expression of cyclooxygenase-2 (COX-2), and of arachidonic acid metabolism, promote the upregulation of proinflammatory cytokines, such as tumour necrosis factor (TNF), interleukin(IL)-1, IL-6 and IL-8, thereby inducing a chronic inflammatory response and the stimulation of more free radicals (Reuter et al., 2010). Extensive data has shown that oxidative stress contributes to the inflammatory process, which, in turn, leads to overproduction of reactive radical species thereby promoting a harmful feedback process that increases cellular damage.

The primary function of the respiratory chain is to use the energy produced to transfer electrons into the mitochondrial intermembrane space. However, a small percentage of electrons escape from the mitochondrial space, producing superoxide (Birben et al., 2012). In normal conditions, the production of superoxide is limited by SOD, which transforms the anion into hydrogen peroxide (Droge, 2002). Under oxidative stress, overproduction of superoxide occurs via activation of nicotine adenine dinucleotide phosphate (NADPH) and depletion of SOD
(Birben et al., 2012). Under oxidative stress, some organelles including peroxisomes, mitochondria and endoplasmic reticulum (ER) are affected by the overproduction of free radicals, mainly associated with lipid peroxidation. The peroxisome damage leads to CAT depletion and intracellular accumulation of $\mathrm{H}_{2} \mathrm{O}_{2}$ (Valko et al., 2007). The mitochondria are an important target for injury induced by oxidative stress caused via endogenous metabolic processes and/or exogenous oxidative influences (Guo et al., 2013). The mitochondrial damage to DNA caused by oxidative stress can result in a decrease in proteins that are important for electron transport, leading to the generation of ROS and the dysregulation of organelles, which, in turn, activate cell apoptotic mechanisms (Van Houten et al., 2006). Furthermore, radicals such as $\mathrm{NO}^{-}$and $\mathrm{ONOO}^{-}$are responsible for detrimental changes in the mitochondrial respiratory chain (Sas et al., 2007). The structural changes in mitochondrial proteins result in altered function in which enzymatic systems of the electron-transport chain (nicotinamide adenine dinucleotide dehydrogenase, cytochrome-c-oxidase, and adenosine triphosphate synthase) are the main targets of the free radicals (Van Houten et al., 2006).

ROS can also alter mitochondrial phospholipids resulting in lipid peroxidation, which, in turn, increases mitochondrial membrane permeability. The mitochondrial permeability transition pore (MPTP) can be induced by ROS generation due the oxidation of thiol groups on the adenine nucleotide translocator (part of the MPTP) (Valko et al., 2007). $\mathrm{ONOO}^{-}$can also affect mitochondrial homeostasis and energy production by inactivating enzymatic systems and promoting the release of mitochondrial $\mathrm{Ca}^{2+}$ (Douarre et al., 2012). The intracellular elevation of the $\mathrm{Ca}^{2+}$ level also changes mitochondrial membrane potential (MMP) and induces the production of superoxide radicals, resulting in a vicious cycle (Douarre et al., 2012) The mitochondrial excess of $\mathrm{Ca}^{2+}$ contributes with the formation of MPTP, to osmotic swelling and rupture of the outer mitochondrial membrane (Douarre et al., 2012). These mitochondrial changes caused by oxidative stress can lead to cell apoptosis due to the release of cytochrome-c, changes in $\mathrm{Bcl} 2 / \mathrm{Bax}$ expression (down-regulation of the $\mathrm{Bcl} 2$ protein and an increase in Bax expression), activation of MAPKs and casp3 (Anuradha et al., 2001; Farley et al., 2006).

The ER is an organelle that regulates protein synthesis, drug detoxification, carbohydrate metabolism, lipid biosynthesis and $\mathrm{Ca}^{2+}$ homeostasis. Oxidative stress and ROS generation deregulate the ER functions and release $\mathrm{Ca}^{2+}$ into the cytosol (Minasyan et al., 2017). The ER and mitochondria interact physiologically and functionally at sites called mitochondrial associated membranes. The damage to ER caused by oxidative stress results in mitochondrial dysfunction and cell apoptosis (Kim et al., 2008). 


\section{Response to mycotoxins and oxidative stress: interaction in in vitro, in vivo and ex vivo models}

The mycotoxins aflatoxin $\mathrm{B}_{1}\left(\mathrm{AFB}_{1}\right)$, deoxynivalenol (DON), nivalenol (NIV), fumonisin $\mathrm{B}_{1}\left(\mathrm{FB}_{1}\right)$, ochratoxin A (OTA), PAT and ZEA are the main contaminants of food and feed worldwide and have been extensively studied due their toxic effects on the human and the animal health (Wu et al., 2014a). Several aspects of the intracellular action of mycotoxins have been elucidated: the induction of oxidative stress and ROS generation have become one of the major triggers of their lesional mechanisms, as observed in in vitro, in vivo and ex vivo studies. The oxidative stress mechanisms associated with $\mathrm{AFB}_{1}, \mathrm{DON}, \mathrm{NIV}, \mathrm{T}-2$ toxin (T-2), FB $\mathrm{F}_{1}$, OTA, PAT and ZEA are summarised in Figure 1 and 2.

\section{Aflatoxin $B_{1}$}

Aflatoxins are fungal metabolites mainly produced by Aspergillus flavus and Aspergillus parasiticus (Saini and Kaur, 2012). More than 10 forms of aflatoxins are known, among which the main ones are $A F B_{1}$, and aflatoxins $B_{2}$ $\left(\mathrm{AFB}_{2}\right), \mathrm{G}_{1}\left(\mathrm{AFG}_{1}\right), \mathrm{G}_{2}\left(\mathrm{AFG}_{2}\right), \mathrm{M}_{1}\left(\mathrm{AFM}_{1}\right)$ and $\mathrm{M}_{2}\left(\mathrm{AFM}_{2}\right)$ (Kumar et al., 2017). Aflatoxins are natural contaminants of cereals (maize, rice, oats, barley and sorghum), groundnuts, pistachio nuts, almonds, cottonseed and walnuts (Wu et al., 2014a). Milk can be contaminated by $\mathrm{AFM}_{1}$, which is a principal hydroxylated-AFB ${ }_{1}$ metabolite biotransformed by hepatic cytochrome $\mathrm{P} 450$ in cows fed an $\mathrm{AFB}_{1}$ contaminated diet (Bennet and Klick, 2003).

The toxicity of $\mathrm{AFB}_{1}$ is mainly associated with the binding of bioactivated $\mathrm{AFB}_{1}$-8,9-epoxide to cellular macromolecules, such as mitochondria, nuclear nucleic acids and nucleoproteins, with cytotoxic effects (Bennet and Klich, 2003).

Studies in vitro (Liu and Wang, 2016; Mary et al., 2012; Wang et al., 2017) and in vivo (Abdel-Wahhab and Aly, 2003; Shi et al., 2015) demonstrated that oxidative stress plays a major role in the toxic effects of $\mathrm{AFB}_{1}$. The main consequences of ROS generation induced by $\mathrm{AFB}_{1}$ are damage to DNA (Wang et al., 2017; Zhang et al., 2015b) and mitochondrial lesions (Liu and Wang, 2016) as summarised in Figure 1. AFB ${ }_{1}$ uncouples mitochondrial oxidative phosphorylation, reduces MMP and induces mitochondrial permeability (Liu and Wang, 2016; Shi et $a l ., 2015)$. The mitochondrial alterations associated with oxidative stress activate cytochrome $\mathrm{C}$, modulate $\mathrm{Bcl} 2 /$ Bax gene expression and activate caspase 9 and caspase 3 (Liu and Wang, 2016; Mary et al., 2017; Wang et al., 2017) leading to cell apoptosis. Mary et al. (2017) also reported that hepatocytes treated with $\mathrm{AFB}_{1}$ increase the expression

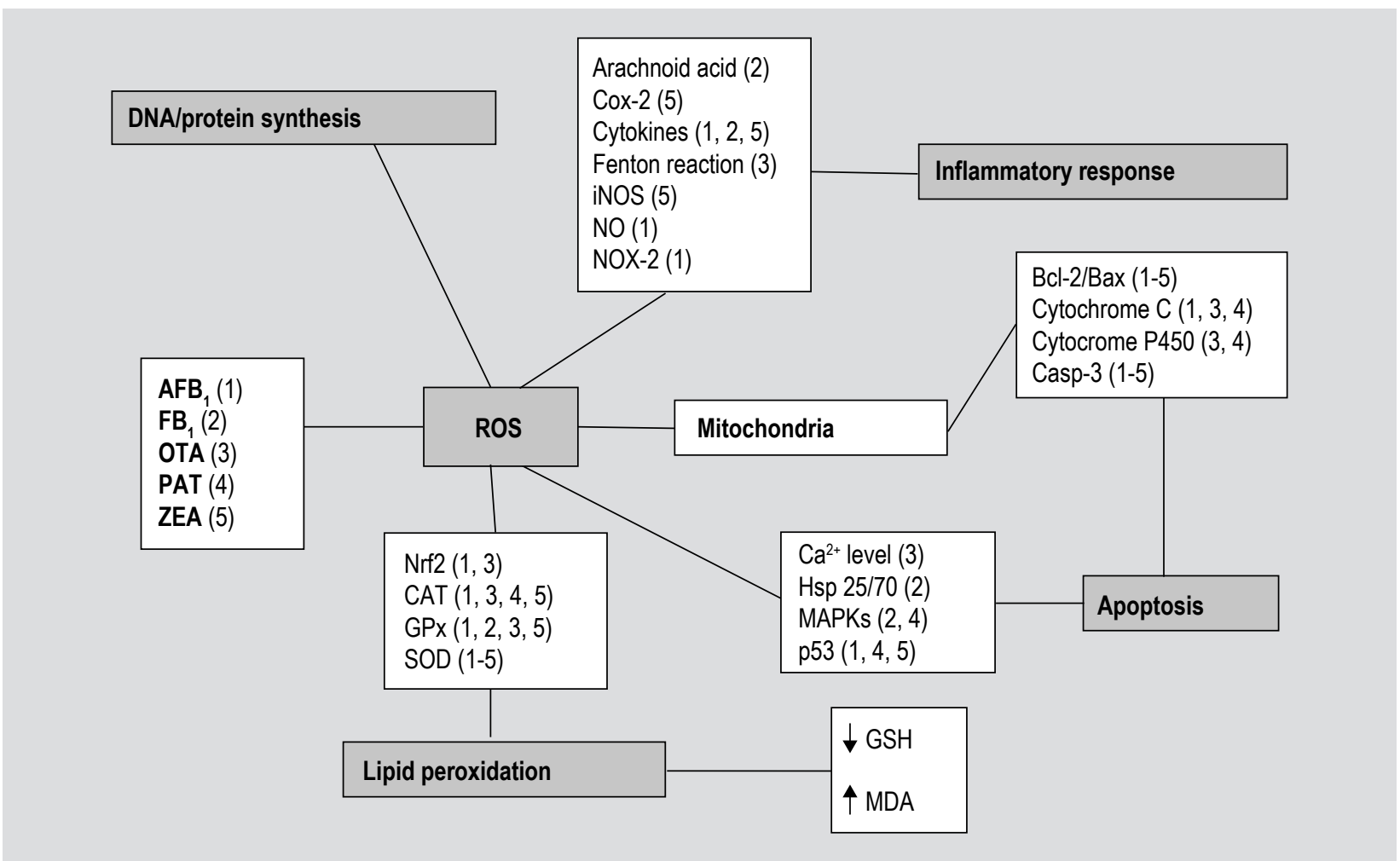

Figure 1. Summary of the intracellular lesions associated with oxidative stress induced by the main mycotoxins that contaminate food and feed. $A F B_{1}=$ aflatoxin $B_{1} ; F_{1}=$ fumonisin $B_{1} ;$ OTA = ochratoxin $A ; P A T=$ patulin; $Z E A=$ zearalenone. The numbers between brackets indicate the mycotoxins involved in each process. 


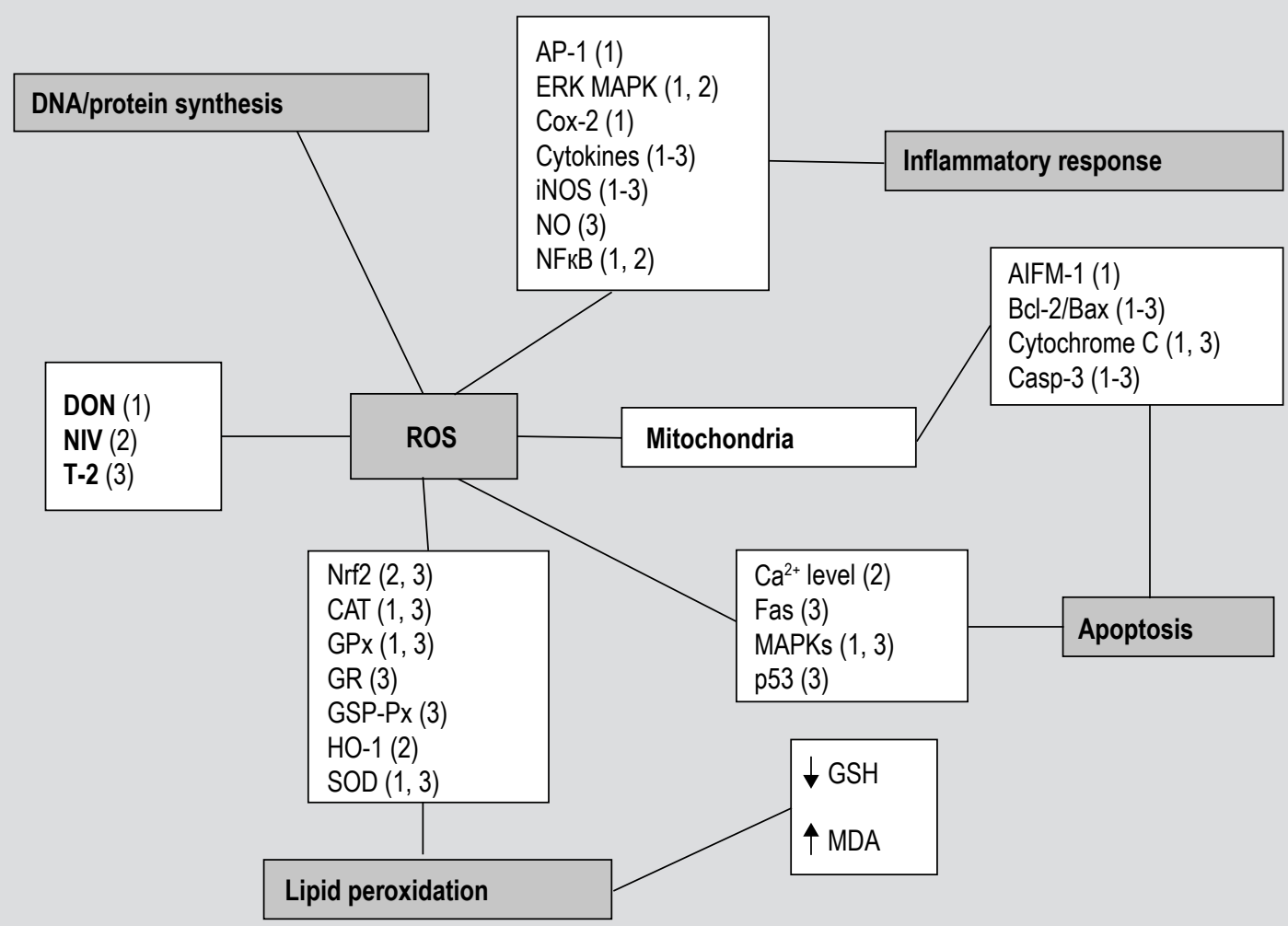

Figure 2. Summary of the intracellular lesions associated with oxidative stress induced by trichothecenes that contaminate food and feed. DON = deoxynivalenol; NIV = nivalenol; T-2 = T-2-toxin. The numbers between brackets indicate the mycotoxins involved in each process.

of the p53 gene, which was associated with an increase in cell apoptosis.

Recent studies have shown that $\mathrm{AFB}_{1}$ causes changes in intracellular antioxidant mechanisms such as Nrf2, SOD, GPx and CAT expression (Liu and Wang et al., 2016; Wang et al., 2017), inhibiting antioxidant enzymes and causing an increase in lipid peroxidation (LPO) and a decrease in the level of GSH (Ma et al., 2015; Maurya and Trigun, 2016). Moreover, ROS generation induced by $\mathrm{AFB}_{1}$ modulates the inflammatory response through up-regulation of pro-inflammatory cytokines TNF- $\alpha$, IL- $1 \alpha$, IL- $1 \beta$ and IL- 6 and NO expression, by reducing anti-inflammatory cytokine IL-4 expression, inducing cytochrome $\mathrm{P} 450$ activity, increasing arachidonic acid metabolism, and activating the NADPH oxidase (NOX)2 dependent signalling pathway, thereby promoting the autophagy of pro-inflammatory macrophages M1 (An et al., 2017; Ma et al., 2015; Meissonier et al., 2007).

\section{Deoxynivalenol}

DON is a type B trichothecene predominantly produced by Fusarium graminearum and Fusarium culmorum (Bennet and Klich, 2003). Exposure to DON has been associated with alterations in the intestinal, immune, endocrine and nervous systems in several animal species and in humans (Maresca et al., 2013; Payros et al., 2016; Pestka, 2010a). At a molecular level, DON causes ribotoxic stress, inducing MAPK phosphorylation, promoting apoptosis, resulting in changes in the inflammatory response and decreasing the expression of cell adhesion proteins (Pierron et al., 2016; Silva et al., 2014).

Studies in vitro (Li et al., 2014; Yang et al., 2014; Zbynovska et al., 2013) and in vivo (Borutova et al., 2008; Osselaere et al., 2013) established the toxic effects of DON associated with oxidative stress and ROS generation as observed in the Figure 2. DON alters the intracellular antioxidant defence system in target tissues such as liver, kidney, lymphoid organs, intestine and blood/serum as demonstrated by an increase in MDA concentration (Li et al., 2014) and a decrease in GSH, SOD, CAT and GPx levels (Hou et al., 2013; Strasser et al., 2013; Zbynovska et al., 2013).

The oxidative stress signalling pathway induced by DON has been suggested to be one of the mechanisms behind DNA fragmentation, cell death and apoptosis (Frankic et al., 2008; Zhang et al., 2009) as well as the inhibition of protein synthesis and an increase in carbonyl content (Strasser et al., 2013). Furthermore, alterations in the surface of lysosomal membranes lead to lysosomal fragility, a decrease 
in the MMP, an increase in membrane permeability and consequent deregulation of $\mathrm{Bcl}-2 / \mathrm{Bax}$ expression (leading to release of cytochrome $C$ and activation of caspase 3,8 , 9 and apoptosis inducing factor mitochondrion associated 1) have been associated with ROS generation induced by DON (Kouadio et al., 2005; Li et al., 2014; Sun et al., 2015). It has also been established that the ribotoxic stress induced by DON can stimulate apoptosis via activation of the p38 MAPK (Pestka et al., 2008).

In addition, DON-induced oxidative stress can modulate the inflammatory response through up-regulation of pro-inflammatory cytokines including IL-1 $\beta$, IL-2, IL6, IL-8, TNF- $\alpha$, down-regulation of anti-inflammatory IL-4 and IL-10, selective activation of ERK MAPK, NFKB and AP-1, and increased and decreased expression of intracellular proteins involved in innate immunity, such as cyclooxygenase-2 (Cox-2) and inducible nitric oxide synthase (iNOS), respectively (Cano et al., 2013; Graziani et al., 2015; Pestka et al., 2010b).

\section{Nivalenol}

NIV is another type B trichothecene and is generally a biologically active metabolite of DON, present in agricultural commodities (Bennet and Klich, 2003). NIV is not as prevalent as DON, but NIV showed higher acute toxicity than DON (Alassane-Kpembi et al., 2015; Cheat et al., 2015). Studies in vivo (Cheat et al., 2015), in vitro (Alassane-Kpembi et al., 2015; Del Regno et al., 2015; Marzocco et al., 2009) and ex vivo (Alassane-Kpembi et al., 2017; Cheat et al., 2015) reported that NIV, such as DON, induce inhibition of protein, DNA and RNA synthesis, mitochondrial damage, cell apoptosis, decreases cellular viability and modulate inflammatory response mainly due to ROS generation associated with induction of oxidative stress as demonstrated in Figure 2, affecting the gastrointestinal tract and organs of the immune system.

The oxidative stress induced by NIV promotes ROS release via the NADPH oxidase signalling pathway, decreases the GSH level, alters $\mathrm{Ca}^{2+}$ homeostasis and activates nuclear factor kappa beta (NF-kB) (Del Regno et al., 2015). This ROS generation induces DNA and mitochondrial damage, activation of extracellular regulated kinase (ERK) MAPK, changes in Bcl-2 expression, up-regulation of Bax gene and activation of caspase 3 , thereby promoting cell apoptosis (Marzocco et al., 2009). The oxidative stress induced by NIV stimulates the antioxidant intracellular mechanisms of defence through an increase in heme oxygenase- 1 (HO-1) and activation of Nrf2 (Del Regno et al., 2015). In addition, the NIV-induced oxidative stress modulates the inflammatory response by activation of NF- $\mathrm{kB}$, upregulation of pro-inflammatory cytokines such as IL-8, IL-1 $\alpha$, IL-1 $\beta$, IL-17A, IL-22, interferon (IFN)- $\alpha$ and an increase in iNOS expression (Alassane-Kpembi et al., 2017; Del Regno et al., 2015; Marzocco et al., 2009).

\section{T-2 toxin}

T-2 is a type A trichothecene produced by several Fusarium species, mainly Fusarium sporotrichiodes, Fusarium poae and Fusarium langsethiae. Studies have demonstrated that T-2 affects the gastrointestinal tract, kidney, liver, heart, skin, the nervous, immunological, and reproductive systems, and embryogenic development in humans and animals (Agrawal et al., 2012; Li et al., 2011; Meissonnier et al., 2008).

The main molecular target of trichothecenes is the ribosomal unit, affecting initiation of the polypeptide chain ( $\mathrm{Li}$ et al., 2011). Like other trichothecenes, T-2 binds and inactivates peptidyl transferase activity resulting in inhibition of protein synthesis and disruption of the mitochondrial morphology, ER and other membranes (Adhikari et al., 2017). Studies in vitro (Chen et al., 2008; Yang et al., 2016; Zhang et al., 2016) and in vivo (Chaudhari and Lakshmana, 2010) provided evidence that $\mathrm{T}$-2-induced oxidative stress is associated with an increase in ROS generation and DNA, protein and lipid peroxidation leading to cell apoptosis.

The oxidative stress induced by T-2 promotes Fas upregulation, p53 activation, down-regulation of $\mathrm{Bcl}-2$ and up-regulation of the pro-apoptotic factor Bax causing cytochrome $\mathrm{C}$ release, caspase 3 activation and cell apoptosis (Chen et al., 2008; Zhang et al., 2018) (Figure 2). ROS generation causes a decrease in Nrf2 expression, changes in the intracellular antioxidant enzymes GPx, GR, SOD and CAT, promoting a decrease in GSH level and an increase in MDA level (Wu et al., 2014b; Yang et al., 2016).

Another apoptosis signalling pathway linked to oxidative stress induced by T-2 is through the activation of JNK1, p38 MAPK, increase in heat shock protein (Hsp) 70 expression, increase in iNOS activity and NO release, causing mitochondrial damage and activation of caspase 3 (Chaudhari and Lakshmana, 2010; Li and Pestka, 2008). In addition, studies have shown that T-2 can modulate the inflammatory response by increasing the expression of pro-inflammatory cytokines such as TNF- $\alpha$, IL-6, IL-1 $\beta$ and IL-11 (Agrawal et al., 2012; Zhou et al., 2014).

\section{Fumonisin $\mathrm{B}_{1}$}

Fumonisins are a group of mycotoxins mainly produced by Fusarium verticillioides and Fusarium proliferatum (Voss et al., 2001). At least 15 related fumonisin compounds have been identified so far, but $\mathrm{FB}_{1}$ is the most significant fumonisin due to its toxicity and widespread occurrence (Voss et al., 2007). 
At cellular level, $\mathrm{FB}_{1}$ inhibits ceramide synthase, blocking the synthesis of sphingolipids, a class of membrane lipids that play an important role in cell signalling transduction pathways and cell growth, differentiation, and death (Grenier et al., 2012; Voss et al., 2007). Ceramide synthase inhibition leads to reduced levels of ceramide and intracellular accumulation of sphingolipids (So) and sphinganine (Sa). These free sphingoid bases are pro-apoptotic, cytotoxic growth inhibitors and are immunotoxic (Loiseau et al., 2007; Voss et al., 2001, 2007).

Studies in vitro (Domijan et al., 2015; Mary et al., 2012) and in vivo (Abbes et al., 2016; Hassan et al., 2015) revealed the potential of $\mathrm{FB}_{1}$ to induce oxidative stress with consequent ROS generation, cytotoxic effects and apoptosis. The action of $\mathrm{FB}_{1}$ on ROS generation has been considered a consequence rather than a mechanism of its toxicity (Galvano et al., 2002; Wang et al., 2016). However, some studies showed that $\mathrm{FB}_{1}$ was able to increase the rate of oxidation, promote the production of free radicals and accelerate the chain reactions associated with lipid peroxidation in membranes (Hassan et al., 2015; Stockmann-Juvala and Savolainen, 2008). These changes were demonstrated in different animal models by alterations in GPx and SOD expression, increase in MDA production and decrease in the GSH level (Abbes et al., 2016; Domijan et al., 2007; Poersch et al., 2014).

The increase in ROS production induced by $\mathrm{FB}_{1}$ has also been associated with inhibition of DNA synthesis and DNA fragmentation (Kouadio et al., 2005; Wang et al., 2016), inhibition of protein synthesis (Domijan et al., 2007), mitochondrial injury with consequent deregulation of calcium homeostasis and caspase 3 activation, induction of cytochrome $\mathrm{P} 450$ activity with an increase in arachidonic acid metabolism and modulation of inflammatory response (Abbes et al., 2016; Domijan and Abramov, 2011; Mary et al., 2017). Some studies have demonstrated that perturbations of the cellular redox state due the $\mathrm{FB}_{1}$ exposition can activate MAPKs and Hsp 25/70. Both signalling pathways can affect cell survival and are involved in the regulation of apoptosis (Lalles et al., 2010; Rumora et al., 2007) (Figure 1).

\section{Ochratoxin A}

Ochratoxins are a group of mycotoxins produced by filamentous fungal species such as Aspergillus and Penicillium and occur in nature in three different isoforms: ochratoxin A, B and C. OTA is the most pathogenic to humans and animals, and is found in a wide range of foods and feed, including cereals, meat, dried fruits, nuts, coffee, wine and beer (Bennet and Klich, 2003; Limonciel and Jennings, 2014; Malir et al., 2016).

Studies involving mammalian species in vitro (Bhat et al., 2016; Gayathri et al., 2015; Lautert et al., 2014; Li et al., 2015) and in vivo (Aydin et al., 2003; Tanaka et al., 2016) showed nephrotoxic, hepatotoxic, immunotoxic, enterotoxic, neurotoxic and teratogenic effects of OTA. The toxicity and carcinogenic mechanisms of OTA have been associated with induction of oxidative stress (Costa et al., 2016), cell apoptosis (Ramyaa and Padma, 2013), cell autophagy/mitophagy (Gan et al., 2017; Qian et al., 2017) and protein synthesis inhibition (Mally and Dekant, 2009).

ROS generation has been reported to trigger OTA toxicity (Zhu et al., 2017). Several oxidative stress mechanisms elicited by OTA have been proposed through in vivo (AbdelWahhab et al., 2017; Gan et al., 2017) and in vitro studies (Bhat et al., 2016; Ramyaa et al., 2014) (Figure 1). OTA can cause damage due to oxidative stress through the generation of hydroxyl radicals via the Fenton reaction, via flavoprotein NADPH-cytochrome P450 activation and inhibition of Nrf2 activation and gene transcription. In addition, OTA can decrease the expression of the intracellular antioxidant enzymes GPx, CAT, SOD and GR (Abdel-Wahhab et al., 2017; Bhat et al., 2016) as demonstrated by an increase in MDA levels.

ROS generation increased by OTA promotes the activation of the apoptosis signalling pathway through the mitochondrial lipid peroxidation, promoting loss of mitochondria membrane potential, increasing membrane permeability (Bhat et al., 2016), activating JNK MAPKs (Zhu et al., 2017) and affecting the ER calcium channels with consequent release of the calcium into cytosol (Sheu et al., 2017). These lesional mechanisms promote changes in the $\mathrm{Bcl}-2$ family, inducing the expression of Bax, facilitating the release of cytochrome $\mathrm{C}$ and the activation of caspase 3 in the cytosol.

\section{Patulin}

PAT is a mycotoxin produced by several fungal species of the genera Penicillium, Aspergillus, Paecilomyces and Byssochlamys and is a common contaminant of apples and its products, rotten fruit, mouldy feed and stored cheese (Tannous et al., in press).

The toxic effects of PAT have been described in vitro (Assunção et al., 2016; Jayashree et al., 2017; Zhang et al., 2015a), in vivo (Boussabbeh et al., 2016b; Lu et al., 2017;) and ex vivo (Maidana et al., 2016) mainly associated with ROS generation and activation of $\mathrm{p} 53$ protein and cleaved caspase 3 (Assunção et al., 2016; Boussabbeh et al., 2016b; Jayashee et al., 2016; Jin et al., 2016) (Figure 1).

PAT has a strong affinity for sulfhydryl groups (Tannous et al., in press). Therefore, the rapid ROS generation observed in the PAT toxicity is likely due to its electrophilic attack of the intracellular antioxidant enzymes containing the sulfhydryl group, mainly GSH (Jin et al., 2016). PAT 
decreases SOD and CAT activity, promoting an increase in MDA levels (Zhang et al., 2015a).

ROS generation also leads to lipid peroxidation, modulation of p38 MAPK expression, injury of cellular membranes and consequent DNA damage (Jin et al., 2016). The activation of p53 is initiated by ROS generation that results in an increase in ROS generation (feedback loop) due to the increase in p53-induced gene 3 (PIG 3) expression that induces the inhibition of anti-oxidant enzyme CAT (Jin et al., 2016). In addition, p53 activation induces mitochondrial damage and caspase 3 activation leading to cell apoptosis (Boussabbeh et al., 2016b). PAT also modulates other mechanisms associated with apoptosis regulation: it decreases Bcl-2 expression and increases Bax, cytochrome C and P450 expression (Boussabbeh et al., 2016b; Jin et al., 2016). Some studies have demonstrated that the generation of ROS causes mitochondrial damage and activates caspase 3 due to ER stress induced by PAT (Boussabbeh et al., 2015, 2016a).

\section{Zearalenone}

ZEA is a resorcylic acid lactone derived mycotoxin produced by Fusarium fungi and is a contaminant commonly found in unprocessed maize kernels. ZEA and its metabolites ( $\alpha$ - and $\beta$-zearalenol) have structural analogy to oestrogens. The oestrogenic activity of ZEA and its derivative has been demonstrated both in vivo (Koraichi et al., 2012) and in vitro (Frizzell et al., 2011; Parveen et al., 2009).

ZEA toxic effects can be induced by mechanisms that are not associated with its oestrogenic activity. ZEA affects the integrity of DNA and mitochondria, decreases cell proliferation and modulates the inflammatory response (Liu et al., 2017; Marin et al., 2015). These cytotoxic and genotoxic effects may be connected with oxidative stress generated by ZEA (Marin et al., 2015). Some studies in vivo (Liu et al., 2017; Marin et al., 2015) and in vitro (Hassen et al., 2007; Qin et al., 2015) demonstrated the capacity of ZEA to induce ROS and lipid peroxidation, causing oxidative DNA and mitochondrial damage, apoptosis and modulation of pro- and anti-inflammatory cytokines as observed in Figure 1. The inhibition of protein and DNA synthesis caused by the oxidative stress was related to fragmentation of DNA, production of micronuclei and formation of DNAadduct (Abid-Essefi et al., 2004). Furthermore, the decrease in cell proliferation could be the result of cell arrest in the G2/M phase induced by ZEA (Abid-Essefi et al., 2003).

The generation of ROS by ZEA exposure led to an increase in iNOS and Cox-2 expression, and up-regulation of proinflammatory and down-regulation of anti-inflammatory cytokines (Marin et al., 2015). Studies in vivo (Liu et al., 2017; Marin et al., 2015) and in vitro (Hassen et al., 2007; Qin et al., 2015) showed that ZEA also increases MDA levels due to the modulation of intracellular antioxidant mechanisms: decrease in GSH levels and SOD activity, increase in GPx and CAT activities. The latter enzymes are involved in intracellular antioxidant activity of the hydrogen peroxide conversion, consequently, the increase in GPx and CAT activities could be associated with an intracellular compensatory mechanism to scavenge ROS generation induced by ZEA (Marin et al., 2015). Recent studies showed that ZEA-ROS generation increased the expression of $\mathrm{p} 53$, decreased MMP, promoting a decrease in anti-apoptotic $\mathrm{Bcl}-2$ gene expression, leading to Bax expression and caspase 3 activation (Fan et al., 2017). Therefore, the mitochondrial damage induced by the oxidative stress due to ZEA exposure can result in cell apoptosis.

\section{Antioxidants and mycotoxins: does a protective effect exist?}

Antioxidants are able to compete with other oxidisable substrates at relatively low concentrations, and thus to significantly delay or inhibit the oxidation of the substrates (Diplock et al., 1998). The physiological role of antioxidants is to prevent damage to cellular components arising as a consequence of chemical reactions involving free radicals. In recent years, studies have demonstrated that the generation of oxidative stress and of free radicals, mainly ROS and RNS, plays an important role in the development of several diseases, including cancer (Reuter et al., 2010; Zuo et al., 2015). Similar protective action of antioxidants, mainly of natural origin, has been observed against the toxic effects of several mycotoxins (Sorrenti et al., 2013).

The protective properties of antioxidants are probably due to their ability to act as free radical scavengers, thereby protecting DNA, cell proteins and lipids from mycotoxininduced damage. Many natural substances have been used for their ability to modulate the oxidative stress caused by mycotoxins, including ascorbate (vitamin C), tocopherol (vitamin E), carotenoid (vitamin A) and the flavonoids (Diplock et al., 1998; Sorrenti et al., 2013; Strasser et al., 2013). Several studies have also demonstrated the ability of crocin, curcumin, green tea, lycopene, phytic acid, L-carnitine, melatonin and minerals to modulate mycotoxin-induced oxidative stress (Meki et al., 2004; Moosavi et al., 2016; Salem et al., 2016; Silva et al., 2014; Verma and Mathuria, 2008; Zheng et al., 2013).

\section{Vitamins}

Vitamins, mainly vitamins $\mathrm{A}, \mathrm{C}$ and $\mathrm{E}$, and their precursors act as free radical scavengers. These vitamins reduce oxidative stress and mycotoxin-induced damage to the cells (Strasser et al., 2013). The main effects of vitamins A, C and $\mathrm{E}$ on the cellular oxidative stress induced by mycotoxins observed in in vitro and in vivo studies are listed in Table 1. 
Table 1. Effects of antioxidant vitamins $A, C$ and $E$ in mycotoxin studies.

\begin{tabular}{|c|c|c|c|}
\hline Mycotoxin $^{1}$ & Experimental model & Antioxidant effects ${ }^{2}$ & Reference \\
\hline \multicolumn{4}{|l|}{ Vitamin A } \\
\hline \multirow[t]{2}{*}{$\mathrm{AFB}_{1}$} & $\begin{array}{l}\text { in vitro: human lymphocytes } \\
\text { in vitro: microsomal enzymes } \\
\text { in vitro: HepG } 2 \text { cells }\end{array}$ & $\begin{array}{l}\text { increase GSH, GPx and SOD; decrease MDA } \\
\text { inhibit microsomal enzymes and reduce the bioactivation of } \mathrm{AFB}_{1} \\
\text { decrease the bioactivation of } \mathrm{AFB}_{1} \text {; decrease apoptosis; inhibit p53 } \\
\text { mutation }\end{array}$ & $\begin{array}{l}\text { Alpsoy et al., } 2009 \\
\text { Wheeler et al., } 2006 \\
\text { Reddy et al., } 2006\end{array}$ \\
\hline & in vivo: mice & decrease the mitotic and meiotic clastogeny & Sinha and Dharmshila, 1994 \\
\hline DON & in vitro: murine lymphoma cells & decrease the lipid (MDA) and protein peroxidation & Strasser et al., 2013 \\
\hline OTA & in vivo: rats & increase GSH and GPx; decrease apoptosis & Palabiyik et al., 2013 \\
\hline ZEA & in vivo: mice & decrease DNA adduct formation & $\begin{array}{l}\text { Ghedira-Chekir et al., 1998; } \\
\text { Grosse et al., } 1997\end{array}$ \\
\hline \multicolumn{4}{|l|}{ Vitamin C } \\
\hline $\mathrm{AFB}_{1}$ & $\begin{array}{l}\text { in vitro: woodchuck hepatocytes } \\
\text { in vitro: human lymphocytes } \\
\text { in vitro: microsomal enzymes } \\
\text { in vivo: rats } \\
\text { in vivo: guinea pig } \\
\text { in vivo: rabbits } \\
\text { in vivo: rohu (Labeo rohita) }\end{array}$ & $\begin{array}{l}\text { decrease DNA adduct formation } \\
\text { increase GSH, GPx and SOD; decrease MAD level } \\
\text { inhibit microsomal enzymes and reduce the bioactivation of } \text { AFB }_{1} \\
\text { increase } \mathrm{AFB}_{1} \text { metabolism to AFM } \\
\text { decrease the GSH level; decrease the cytochrome } \mathrm{P}_{4} 50 \text { level } \\
\text { decrease the number of abnormal and dead sperms } \\
\text { increase serum lysozyme activity; enhance phagocytic ratio; } \\
\text { immunostimulatory effect }\end{array}$ & $\begin{array}{l}\text { Yu et al., } 1994 \\
\text { Alpsoy et al., } 2009 \\
\text { Wheeler et al., } 2006 \\
\text { Gradelet et al., } 1998 \\
\text { Netke et al., } 1997 \\
\text { Salem et al., } 2001 \\
\text { Sahoo and Mukherjee, } 2003\end{array}$ \\
\hline DON & $\begin{array}{l}\text { in vitro: rat erythrocytes } \\
\text { in vitro: murine lymphoma cells } \\
\text { in vivo: rats }\end{array}$ & $\begin{array}{l}\text { decrease the haemolytic effect } \\
\text { decrease the lipid (MDA) and protein peroxidation } \\
\text { increase the CAT, SOD and GST activities; increase GSH level; } \\
\text { decrease MDA level }\end{array}$ & $\begin{array}{l}\text { Rizzo et al., } 1992 \\
\text { Strasser et al., } 2013 \\
\text { Atroshi et al., 1995; } \\
\text { Rizzo et al., } 1994\end{array}$ \\
\hline OTA & in vivo: mice & decrease apoptosis & Atroshi et al., 2000a \\
\hline $\mathrm{T}-2$ & $\begin{array}{l}\text { in vitro: rat erythrocytes } \\
\text { in vivo: rats }\end{array}$ & $\begin{array}{l}\text { decrease the haemolytic effect } \\
\text { increase CAT, SOD, GST and GSH level }\end{array}$ & $\begin{array}{l}\text { Rizzo et al., } 1992 \\
\text { Atroshi et al., 1995; } \\
\text { Rizzo et al., } 1994\end{array}$ \\
\hline ZEA & $\begin{array}{l}\text { in vivo: piglets } \\
\text { in vivo: mice }\end{array}$ & $\begin{array}{l}\text { increase T-AOC, SOD and GPx; decrease MDA level } \\
\text { decrease DNA adduct formation }\end{array}$ & $\begin{array}{l}\text { Shi et al., } 2017 \\
\text { Ghedira-Chekir et al., 1998; } \\
\text { Grosse et al., } 1997\end{array}$ \\
\hline \multicolumn{4}{|l|}{ Vitamin $\mathrm{E}$} \\
\hline \multirow[t]{4}{*}{$\mathrm{AFB}_{1}$} & in vitro: HepG2 cells & $\begin{array}{l}\text { decreased p53 mutation; decreased DNA adduct formation; } \\
\text { decreased apoptosis }\end{array}$ & $\begin{array}{l}\text { Reddy et al., 2006; } \\
\text { Abdel-Hamid and Firgany, } 2015\end{array}$ \\
\hline & in vitro: human lymphocytes & increased GST, GPx and SOD; decreased MDA level & Alpsoy et al., 2009 \\
\hline & in vitro: microsomal enzymes & $\begin{array}{l}\text { inhibited of microsomal enzymes and reduce the bioactivation of } \\
\text { AFB }_{1} \\
\text { increased the CAT, SOD and GST; decreased MDA level; decreased } \\
\text { cytochrome P- } 450 \text { activity }\end{array}$ & $\begin{array}{l}\text { Wheeler et al., } 2006 \\
\text { Cassandi et al., } 1993\end{array}$ \\
\hline & in vivo: mice & $\begin{array}{l}\text { increased } 3 \beta \text { - and } 17 \beta \text {-hydroxysteroid dehydrogenases activities and } \\
\text { serum testosterone levels }\end{array}$ & Verma and Nair, 2002 \\
\hline DON & $\begin{array}{l}\text { in vitro: rat erythrocytes } \\
\text { in vitro: murine lymphoma cells } \\
\text { in vivo: piglets } \\
\text { in vivo: rats }\end{array}$ & $\begin{array}{l}\text { decreased the haemolytic effect } \\
\text { decreased the lipid (MDA) and protein peroxidation } \\
\text { decreased DNA damage } \\
\text { increased the CAT, SOD and GST and GSH level; decreased MDA } \\
\text { level }\end{array}$ & $\begin{array}{l}\text { Rizzo et al., } 1992 \\
\text { Strasser et al., } 2013 \\
\text { Frankic et al., } 2008 \\
\text { Atroshi et al., } 1995 ; \\
\text { Rizzo et al., } 1994\end{array}$ \\
\hline $\mathrm{FB}_{1}$ & in vivo: rats & $\begin{array}{l}\text { decrease DNA fragmentation; decreased the } \mathrm{Ca}^{2+} \text { nuclei; decreased } \\
\text { the AST/ALT }\end{array}$ & Atroshi et al., 1999 \\
\hline OTA & $\begin{array}{l}\text { in vitro: porcine fibroblasts } \\
\text { in vitro: HepG } 2 \text { cells } \\
\text { in vivo: rats } \\
\text { in vivo: mice }\end{array}$ & $\begin{array}{l}\text { decreased DNA fragmentation } \\
\text { decreased DNA fragmentation, Bax expression and casp-3 activation } \\
\text { increase the protein level; decreased the AST, ALT, AP and yGT } \\
\text { decreased apoptosis }\end{array}$ & $\begin{array}{l}\text { Fusi et al., } 2010 \\
\text { Gayathri et al., } 2015 \\
\text { Atroshi et al., 2000b } \\
\text { Atroshi et al., 2000a }\end{array}$ \\
\hline
\end{tabular}


Table 1. Continued.

\begin{tabular}{|c|c|c|c|}
\hline Mycotoxin $^{1}$ & Experimental model & Antioxidant effects ${ }^{2}$ & Reference \\
\hline Vitamin E & & & \\
\hline $\begin{array}{l}\text { PAT } \\
\text { T-2 }\end{array}$ & $\begin{array}{l}\text { in vitro: HepG2 cells } \\
\text { in vitro: chicken lymphocytes } \\
\text { in vitro: Vero cells } \\
\text { in vitro: rat erythrocytes } \\
\text { in vivo: chicken } \\
\text { in vivo: rats } \\
\text { in vivo: } \text { mice }\end{array}$ & $\begin{array}{l}\text { decreased p53 activation; decreased DNA damage } \\
\text { increased lymphocyte proliferation } \\
\text { decreased Hsp } 70 \text { expression } \\
\text { decreased the haemolytic effect } \\
\text { decreased MDA level } \\
\text { increased the CAT, SOD and GST and GSH level; increase the } \\
\text { protein level; decreased MDA level, AST, ALT, AP and yGT. } \\
\text { decreased DNA adduct formation }\end{array}$ & $\begin{array}{l}\text { Ayed-Boussema et al., } 2013 \\
\text { Jaradat et al., } 2006 \\
\text { El Golli et al., } 2006 \\
\text { Rizzo et al., } 1992 \\
\text { Hoehler and Marquardt, } 1996 \\
\text { Atroshi et al., 1995, 2000a.; } \\
\text { Rizzo et al., } 1994 \\
\text { Ghedira-Chekir et al., 1998; } \\
\text { Grosse et al., } 1997\end{array}$ \\
\hline
\end{tabular}

Vitamin A has three active forms: retinol, retinal, and retinoic acid (retinoids), which are essential for physiological functions, including reproduction, vision, growth, and maintenance of epithelial tissues. The antioxidative effects of vitamin A have been associated with inhibiting cytochrome P450-mediated metabolism of toxic substances and preventing mutagenic epoxies from binding to DNA, thereby forming epoxides and competing with mutagenic epoxides in reaction with DNA (Diplock et al., 1998). The toxic effects of $\mathrm{AFB}_{1}$, DON, OTA and ZEA have been shown to be reduced in interaction with vitamin $\mathrm{A}$ in in vitro and in vivo models. The beneficial effects include increased levels of antioxidant enzymes (GSH, GPx), a decrease in mycotoxin bioactivation and in cell death (Table 1).

Vitamin C or ascorbic acid is a lactone synthesised in the liver of many species. It is a first-line antioxidant that has beneficial effects including protecting cell membranes, proteins and nucleic acids from oxidation. Its biological action and antioxidant characteristic are associated with its ability to donate electrons. At physiological levels, vitamin C is a powerful scavenger of oxygen-derived free radicals such as superoxide radical anion, $\mathrm{H}_{2} \mathrm{O}_{2}$, the hydroxyl radical, and singlet oxygen in plasma and tissues (Diplock et al., 1998). In addition, ascorbic acid is an efficient scavenger of reactive nitrogen oxide species, thereby avoiding nitrosative stress and cell damage (Rock et al., 1996). Vitamin C also interacts with $\mathrm{GSH}$, reducing $\mathrm{GSH}$ production, which, in turn, reduces oxidative stress. The main effects of vitamin $C$ on mycotoxin induced-toxicity are reducing lipid peroxidation and increasing levels of antioxidant enzymes. These and other effects have been described for $\mathrm{AFB}_{1}$, DON, OTA, T-2 and ZEA (Table 1). Reduced adduct formation, decreased apoptosis and enhancement of phagocytosis have been reported for $\mathrm{AFB}_{1}$ and ZEA (Ghedira-Chekir et al., 1998; Sahoo and Mukherjee, 2003).

Vitamin E refers to a group of substances that includes tocols and tocotrienol derivatives. There are two forms of vitamin $\mathrm{E}, \gamma$-tocopherol and $\alpha$-tocopherol. $\alpha$-tocopherol is the most biologically active form of vitamin $\mathrm{E}$ (Traber and Sies, 1996) and the major function is that of a peroxyl radical scavenger, interrupting the propagation of free radicals. In addition, vitamin $\mathrm{E}$ interacts with reactive nitrogen oxide species and singlet oxygen, thereby maintaining the integrity of polyunsaturated fatty acids in cell membranes (Rock et al., 1996). Vitamin $E$ has been shown to act favourably against seven mycotoxins $\left(\mathrm{AFB}_{1}, \mathrm{DON}, \mathrm{FB}_{1}\right.$, OTA, PAT, T-2 and ZEA) (Table 1). Its actions are similar to those of vitamins $A$ and $C$, although decreased DNA fragmentation and damage of DON, FB 1 and OTA was also reported (Atroshi et al., 1999; Frankic et al., 2008; Gayathri et al., 2015). In addition, reduced Hsp 70 expression and increased lymphocyte proliferation were described for T-2 (El Golli et al., 2006; Jaradat et al., 2006).

\section{Flavonoids}

The flavonoids are the most common hydroxylated phenolic substances that are synthesised by plants. Sources of flavonoids are citrus fruits, berries, red wine and tea (Diplock et al., 1998). The function of flavonoids is associated with its structure, which includes a number of structurally different subgroups, including flavonols (quercetin, kaempferol, myricetin), flavanols (catechin and epicatechin), isoflavones (genistein), flavones (apigenin, hesperetin), flavanones 
(naringenin, taxifolin) and/or anthocyanidins (cyanidin, malvidin) (Rice-Evans and Miller, 1996). The biological function of antioxidants is connected with their capacity to scavenger free radicals (peroxyl radical and hydroxyl radical), as well as chelating metals involved in the Fenton reaction (Rice-Evans and Miller, 1996).

The flavonol quercetin is one of the most effective polyphenolic substances linked to a reduction in the levels of ROS and reactive nitrogen species. In previous in vivo and in vitro studies, quercetin was shown to modulate the effects of oxidative stress caused by $\mathrm{T}-2, \mathrm{AFB}_{1}$ and OTA resulting in an increase in Nrf2 expression, SOD and GPx activity as well as total antioxidant status and GSH levels (Abdel-Wahhab et al., 2017; Capcarova et al., 2015; Choi et al., 2010; Ramyaa and Padma, 2013; Ramyaa et al., 2014). On the other hand, quercetin was associated with a decrease in ER oxidative stress, ROS generation, MAD level, P450 and NADPH activity, cytochrome $C$ release, casp- 3 activation cell apoptosis, Cox- 2 and NO expression, TNF- $\alpha$, IL- 6 and IL-2 and a decrease in DNA damage (Abdel-Wahhab et al., 2017; Ramyaa and Padma, 2013; Ramyaa et al., 2014).

Recent studies demonstrated the antioxidant effects of other flavonoids on oxidative stress induced by mycotoxins. Proanthocyanidin increased Nrf2 expression, SOD, GPx, CAT activities, GSH level, and decreased MDA content, DNA damage and the expression of pro-inflammatory cytokines (IL-1 $\beta$, TNF- $\alpha$, IL- 6 and IFN- $\gamma$ ) in rats and mice subjected to $\mathrm{AFB}_{1}$ (Long et al., 2016c) and ZEA (Long et al., 2016b) diets. Cyanidin decreased DNA damage, ROS production, lipid hydroperoxide and iNOS, and increased HO-1 activity and non-protein thiol groups in rats, in a pig kidney cell line (LLC-PK1), and in human fibroblasts exposed to OTA (Sorrenti et al., 2012). Baicalein, wogonin and hesperidin increased cell viability and decreased genotoxicity and casp-3 activation in mice and neural crest cells exposed to $\mathrm{AFB}_{1}$ (Nones et al., 2013; Ueng et al., 2001). Zhong et al. (2017) reported that the apigenin re-established MMP, increased Bcl-2 expression, decreased Bax, p53 activation and the cytochrome $\mathrm{C}$ release in human embryonic kidney cells 293 (HEK 293 cells) treated with PAT. With the addition of silymarin to their diet, mice subjected to $\mathrm{FB}_{1}$ contaminated feed showed decreased TNF- $\alpha$ expression and casp-8 activation (Sozmen et al., 2014).

\section{Crocin, curcumin, green tea, lycopene and phytic acid}

Crocin is a major bioactive compound and is mainly found in Gardenia jasminoides and saffron. Water and ethanol extracts of crocin displayed antioxidant activity against $\mathrm{O}_{2}{ }^{-}$and $\mathrm{HO}$ radicals (Xiao et al., 2017). Curcumin is a hydrophobic polyphenol derived from turmeric, a compound extracted from the root of Curcuma longa L. rhizome. Curcumin has diverse biological functions and its structure, which is composed of methoxy groups and phenols, is associated with its properties (Zheng et al., 2017). The antioxidant action of crocin and curcumin on the molecular effects of mycotoxins in vitro and in vivo are summarised in Table 2.

Green tea is derived from Camellia sinensis leaves and contains a wide range of bioactive compounds of which one third are composed of polyphenols of which the majority are flavonoids. Catechins (GTCs) are one of the main flavonoids in green tea. GTCs have antioxidant capacity to scavenge ROS such as $\mathrm{O}_{2}^{-}, \mathrm{H}_{2} \mathrm{O}_{2}$ and $\mathrm{HO}$ radicals (Cooper et al., 2005). Lycopene is the most abundant carotenoid (nonvitamin $\mathrm{A}$ ) in orange fruits and vegetables, mainly tomatoes and derived products and is responsible for their bright red colour. Lycopene is a recognised antioxidant and has been considered the most efficient in scavenging single oxygen (Mordente et al., 2011). Phytic acid (IP6) is a saturated cyclic acid commonly found in plant tissues and seeds; and its antioxidant effect is on ROS production mainly due its capacity to chelate iron, thereby inhibiting the Fenton reaction (Silva and Bracarense, 2016). The antioxidant effects of green tea, lycopene and IP6 on mycotoxin-induced oxidative stress in vitro and in vivo studies are listed in Table 3.

\section{L-carnitine}

L-carnitine is an endogenous mitochondrial membrane compound that plays a prominent role in facilitating the transport of long-chain fatty acids into mitochondria and the oxidation pathway (Adeva-Andany et al., 2017). L-carnitine decreases oxidative stress, increases endogenous antioxidant defence capacity, protects mitochondria against lipid oxidation, and decreases apoptosis through the inhibition of mitochondrial swelling and cytochrome $\mathrm{C}$ release (AdevaAndany et al., 2017). L-carnitine has been shown to decrease ROS production, MDA level, casp-3 activation, DNA and protein damage, and to increase MMP and GSH levels in rats and quails subjected to $\mathrm{AFB}_{1}$ or T-2 contaminated diets (Citil et al., 2005; Moosavi et al., 2016; Yatim and Sachan, 2001).

\section{Melatonin}

Melatonin is a hormonal product of the pineal gland that controls reproductive functions, modulates immune system activity, limits tumorigenesis and effectively inhibits oxidative stress (Reiter, 1997). Antioxidant effects of melatonin reported in rats exposed to $\mathrm{AFB}_{1}$ and OTA contaminated diets included an increase in the GHS level and in the activity of CAT, GPx, GSH, GST, GR and SOD (Abdel-Wahhab et al., 2005; Meki et al., 2004; Sutken et al., 2007), a decrease in MDA and LPO content (Abdel-Wahhab et al., 2005; Sutken et al., 2007; Yenilmez et al., 2010) and decreased expression of NO, Hsp 70 and casp-3 (Meki et al., 2001, 2004). 
Table 2. Effects of antioxidant food compounds (crocin and curcumin) in mycotoxins studies.

\begin{tabular}{|c|c|c|c|}
\hline Mycotoxin $^{1}$ & Experimental model & Antoxidant effects ${ }^{2}$ & Reference \\
\hline \multicolumn{4}{|l|}{ Crocin } \\
\hline $\mathrm{AFB}_{1}$ & in vivo: rats & increase GSH level, GPx and GST activities; decrease DNA damage & $\begin{array}{l}\text { Lin and Wang, 1986; } \\
\text { Wang et al., } 1991\end{array}$ \\
\hline PAT & in vivo: mice & $\begin{array}{l}\text { increase GSH level and Bcl-2 expression; re-establish the MMP; } \\
\text { decrease p53 activation, Bax expression and cytochrome } \mathrm{C} \text { release; } \\
\text { decrease MDA content, Hsp } 70 \text { expression, casp-3 activation and } \\
\text { CAT; decrease DNA damage }\end{array}$ & Boubassabbeh et al., 2016a,b \\
\hline \multirow[t]{2}{*}{ ZEA } & $\begin{array}{l}\text { in vitro: HCT11 and HEK293 } \\
\text { cells }\end{array}$ & decrease MDA content, ER stress and DNA damage & Ben Salem et al., 2015b \\
\hline & in vivo: mice & $\begin{array}{l}\text { increase Bcl-2 expression; decrease Bax, Hsp } 70 \text { expression and } \\
\text { p53 activation; decrease MDA content, CAT and SOD activities; } \\
\text { decrease protein carbonyl generation }\end{array}$ & $\begin{array}{l}\text { Ben Salem et al., 2015a; } \\
\text { Salem et al., } 2016\end{array}$ \\
\hline \multicolumn{4}{|l|}{ Curcumin } \\
\hline \multirow[t]{4}{*}{$\mathrm{AFB}_{1}$} & $\begin{array}{l}\text { in vitro: human primary } \\
\text { hepatocytes }\end{array}$ & decrease DNA damage & Gross-Steinmeyer et al., 2009 \\
\hline & in vivo: broiler chickens & $\begin{array}{l}\text { increase GSH level, CAT, GST and SOD activities; decrease } \\
\text { cytochrome P450 expression; decrease IL-6 expression }\end{array}$ & $\begin{array}{l}\text { Gowda et al., 2009; } \\
\text { Yarru et al., } 2009\end{array}$ \\
\hline & in vivo: mice & $\begin{array}{l}\text { increase ATPase and SDH; increase GSH level, CAT, GPx and SOD } \\
\text { activities; decrease DNA and protein damage }\end{array}$ & $\begin{array}{l}\text { Mathuria and Verma, 2007a,b; } \\
\text { Verma and Mathuria, 2008, } \\
\text { 2009; Verma et al., } 2008\end{array}$ \\
\hline & in vivo: rats & $\begin{array}{l}\text { increase GSH level, CAT, SOD, GPx and GST activities; increase } \\
\text { Bcl-2 expression; decrease Bax expression; decrease casp-3 } \\
\text { activation; decrease DNA and protein adduct formation }\end{array}$ & $\begin{array}{l}\text { Abdel-Wahhab et al., 2016; } \\
\text { El-Bahr, 2015; Nayak and } \\
\text { Sashidhar, 2010; }\end{array}$ \\
\hline \multirow[t]{2}{*}{ ZEA } & in vivo: rats & decrease MDA content; decrease DNA fragmentation & Ismaiel et al., 2015 \\
\hline & in vivo: sow & increase GSH level, CAT and SOD activities & Qin et al., 2015 \\
\hline
\end{tabular}

\section{Minerals}

Several minerals are dietary constituents involved in the antioxidant defence system, acting directly as antioxidants or promoting detoxifying enzymes (Sorrenti et al., 2013). Antioxidant enzymes, such as GPx and SOD require a dietary supply of selenium $(\mathrm{Se})$, copper $(\mathrm{Cu})$ and zinc $(\mathrm{Zn})$ (Wang et al., in press).

Se is an essential micronutrient associated with Sedependent enzymes, including GPx, thioredoxin reductases, iodothyronine deiodinases, and selenophosphate synthetases (Wang et al., 2016). Se has been shown to increase the antioxidant function of CAT, GSH, GPx and SOD, decrease MDA content, increase the level of GSH and to modulate DON-induced immunosuppression in piglet lymphocytes and broiler chickens exposed to DON (Placha et al., 2009; Wang et al., in press). Long et al. (2016a,b) observed that Se increased GPx and SOD activities and Bcl-2 expression, decreased MDA content, Bax and casp-3 expression in mice fed with ZEA.

$\mathrm{Zn}$ exerts its antioxidant activity either in an acute way or on a long-term basis. In the first form, zinc acts by stabilising protein sulfhydryl groups against oxidation and exchanging redox active metals (copper and iron) (Zheng et al., 2013). In the second form, $\mathrm{Zn}$ induces the expression of metallothioneins, which act as electrophilic scavengers. Moreover, zinc is a co-factor of the SOD enzyme that catalyses superoxide anions into less toxic $\mathrm{O}_{2}$ and $\mathrm{H}_{2} \mathrm{O}_{2}$ and modulates the activity of GPx and glutamylcysteine synthetase, through the activation of metal response transcription factor-1 (MTF-1) (Powell, 2000). Zheng et al. (2013) demonstrated the antioxidant effect of zinc as being an increase in SOD activity and a decrease in ROS generation and in DNA damage in HepG2 cells exposed to OTA. 
Table 3. Effects of antioxidant food compounds (green tea/catechin, lycopene and phytic acid) in mycotoxins studies.

\begin{tabular}{|c|c|c|c|}
\hline Mycotoxin $^{1}$ & Experimental model & Antoxidant effects ${ }^{2}$ & Reference \\
\hline \multicolumn{4}{|c|}{ Green tea/catechin } \\
\hline \multirow[t]{4}{*}{$\mathrm{AFB}_{1}$} & in vitro: chicken hepatocytes & $\begin{array}{l}\text { increase Bcl2-expression; increase SOD, CAT, GR activities; decrease } \\
\text { MDA content; decrease Bax and NF-KB expression; decrease TNF- } \alpha \text {, IL-1 } 1 \beta \\
\text { and IL-6 expression }\end{array}$ & Oskoueian et al., 2015 \\
\hline & in vitro: HepG2 & decrease ROS production & Corcuera et al., 2012 \\
\hline & in vivo: piglets & decrease the cytochrome 450 content & Tulayakul et al., 2007 \\
\hline & in vivo: rats & $\begin{array}{l}\text { decrease the cytochrome } 450 \text { content; decrease DNA damage; decrease } \\
\text { cell proliferation (promotion phase cancer) }\end{array}$ & $\begin{array}{l}\text { Ito and Ito, 2007; } \\
\text { Qin et al., } 2000\end{array}$ \\
\hline $\mathrm{FB}_{1}$ & in vivo: rats & increase GSH level & Marnewick et al., 2009 \\
\hline OTA & in vitro: LLC-PK1 cells & increase cell viability; decrease ROS production; decrease DNA damage & Costa et al., 2007 \\
\hline PAT & in vivo: mice & $\begin{array}{l}\text { increase GSH level; decrease MDA content; decrease protein carbonyl } \\
\text { formation; decrease p53 and casp-3 activation; decrease DNA damage }\end{array}$ & $\begin{array}{l}\text { Jayashree et al., 2017; } \\
\text { Song et al., } 2014\end{array}$ \\
\hline \multicolumn{4}{|l|}{ Lycopene } \\
\hline $\mathrm{AFB}_{1}$ & in vivo: rats & decrease DNA adduct formation & Tang et al., 2007 \\
\hline OTA & in vivo: rats & $\begin{array}{l}\text { increase GSH level and GPx activity; decrease MDA content; decrease } \\
\text { apoptosis; decrease DNA damage }\end{array}$ & $\begin{array}{l}\text { Aydin et al., 2013; } \\
\text { Palabyik et al., } 2013\end{array}$ \\
\hline $\mathrm{T}-2$ & in vivo: chicks & increase GSH level; decrease MDA content & Leal et al., 1999 \\
\hline ZEA & in vivo: mice & $\begin{array}{l}\text { increase GSH level; increase CAT, GPx, GST, GR and SOD activities; } \\
\text { increase IL-10 expression; decrease TNF- } \alpha, \text { IL-1 } 1 \beta \text {, IL-2 and IL-6 expression }\end{array}$ & Boeira et al., 2015 \\
\hline \multicolumn{4}{|l|}{ Phytic acid } \\
\hline $\mathrm{AFB}_{1}$ & in vivo: rats & increase GSH level; increase CAT and SOD activities & $\begin{array}{l}\text { Abu El-Saad and } \\
\text { Mahmoud, } 2009\end{array}$ \\
\hline \multirow[t]{2}{*}{ DON } & in vitro: IPEC-1 cells & increase TEER & Pacheco et al., 2012 \\
\hline & ex vivo: piglet intestine & decrease Cox-2 and casp-3 expression & Silva et al., 2014 \\
\hline $\mathrm{FB}_{1}$ & ex vivo: piglet intestine & decrease Cox-2 and casp-3 expression & Silva et al., 2014 \\
\hline
\end{tabular}

\section{Mixtures}

Several studies have demonstrated that mixtures of natural substances reduce the oxidative stress lesions caused by mycotoxins. The combination of L-carnitine, vitamin E, selenium, melatonin, coenzyme Q10 and tamoxifen (Abidin et al., 2013; Atroshi et al., 2000; Sutken et al., 2007; Yenilmez et al., 2010) increased protective effects on DNA, proteins and lipids against OTA-induced toxicity compared to the individual effects of the compounds. Moreover, the combination of coenzyme Q10, L-carnitine, alpha-tocopherol and selenium, garlic and curcumin (ElBarbary, 2016), black tea and curcumin (Alm-Eldeen et al., 2015) displayed potent antioxidant effects against the toxic effects of $\mathrm{AFB}_{1}$. In T-2-induced oxidative stress experiments, the increase in the level of GSH and the decrease in DNA damage were more apparent in mixtures of coenzyme Q10, L-carnitine, alpha-tocopherol and selenium (Atroshi et al., 1999) and tamoxifen, vitamin E, and Se (Atroshi et al., 1997, 2000).

\section{Conclusions}

Oxidative stress, ROS and RNS generation induced by mycotoxins have been associated with their cytotoxic effects on DNA, protein synthesis and mitochondria. These effects have been confirmed in different assays on cell membranes, proteins or nucleic acids, but the mechanisms involved in the activation of the signalling pathways that results in cell death or increased permeability for the different mycotoxins remain uncertain. Which factors are involved in activation? Dose, duration of exposure, and animal species are some of the aspects that need to be investigated in addition to the molecular characteristics of mycotoxins. In addition, most available data were acquired in in vitro studies or mice/rat models. New data from other animal models, especially those of economic interest are still lacking. 
Several antioxidants have demonstrated their beneficial effects in mitigating and/or preventing the toxic effects of mycotoxins in in vitro, in vivo and ex vivo experimental models, but again the mechanisms and pathways involved in these effects are still not fully understood, pointing to a wide range of research opportunities. Although numerous studies have demonstrated the protective and preventive effect of antioxidants on mycotoxins-induced oxidative stress, the choice of the most appropriate nutritional methods requires knowledge of the type of antioxidants in the diet, their bioavailability and food sources, and the exact intake required to achieve these protective effects.

\section{References}

Abbes, S., Ben Salah-Abbes, J., Jebali, R., Younes, R.B. and Queslati, R., 2016. Interaction of aflatoxin $B_{1}$ and fumonisin $B_{1}$ in mice causes immunotoxicity and oxidative stress: possible protective role using lactic acid bacteria. Journal of Immunotoxicology 13: 46-54.

Abdel-Hamid, A.A.M. and Firgany, A.E.-D.L., 2015. Vitamin E supplementation ameliorates aflatoxin B1-induced nephrotoxicity in rats. Acta Histochemica 117: 767-779.

Abdel-Wahhab, M.A., Abdel-Galil, M.M. and El-Lithey, M., 2005. Melatonin counteracts oxidative stress in rats fed an ochratoxin A contaminated diet. Journal of Pineal Research 38: 130-135.

Abdel-Wahhab, M.A., Aljawish, A., El-Nekkety, A.A., Abdel-Aziem, S.H. and Hassan, N.S., 2017. Chitosan nanoparticles plus quercetin suppress the oxidative stress, modulate DNA fragmentation and gene expression in the kidney of rat fed ochratoxin A-contaminated diet. Food and Chemical Toxicology 99: 209-221.

Abdel-Wahhab, M.A., Salman, A.S., Ibrahim, M.I., El-Kady, A.A., Abdel-Aziem, S.H., Hassan, N.S. and Waly, A.I., 2016. Curcumin nanoparticles loaded hydrogels protects against aflatoxin $B_{1}$-induced genotoxicity in rat liver. Food and Chemical Toxicology 94: 159-171.

Abid-Essefi, S., Baudrimont, I., Hassen, W., Ouanes, Z., Mobio, T.A., Anane, R., Creppy, E.E. and Bacha, H., 2003. DNA fragmentation, apoptosis and cell cycle arrest induced by zearalenone in cultured DOK, Vero and Caco-2 cells: prevention by Vitamin E. Toxicology 192: 237-248.

Abid-Essefi, S., Ouanes, Z., Hassen, W., Baudrimont, I., Creppy, E. and Bacha, H., 2004. Cytotoxicity inhibition of DNA and protein syntheses and oxidative damage in cultured cells exposed to zearalenone. Toxicology in vitro 18: 467-474.

Abidin, Z., Khan, M.Z., Khatoon, A., Saleemi, M.K., Khan, A. and Javed, I., 2013. Ameliorative effects of L-carnitine and vitamin $\mathrm{E}$ ( $\alpha$-tocopherol) on haematological and serum biochemical parameters in White Leghorn cockerels given ochratoxin A contaminated feed. British Poultry Science 54: 471-477.

Abu El-Saad, A.S. and Mahmoud, H.M., 2007. Phytic acid exposure alters aflatoxinB1-induced reproductive and oxidative toxicity in albino rats (Rattus norvegicus). Evidence-Based Complementary and Alternative Medicine. 6: 332-341.

Adeva-Andany, M.M., Calvo-Castro, I., Fernandez-Fernandez, C., Donapetry-Garcia, C. and Pedre-Pineiro, A.M., 2017. Significance of L-carnitine for human health. IUBMB Life 69: 578-594.
Adhikari, M., Negi, B., Kaushik, N., Adhikari, A., Al-Khedhairy, A.A., Kaushik, N.K. and Choi, E.H., 2017. T-2 mycotoxin: toxicological effects and decontamination strategies. Oncotarget 8: 33933-33952.

Agrawal, M., Yadav, P., Lomash, V., Bhaskar, A.S. and Lakshmana Rao, P.V., 2012. T-2 toxin induced skin inflammation and cutaneous injury in mice. Toxicology 302: 255-265.

Alassane-Kpembi, I., Puel, O. and Oswald, I.P., 2015. Toxicological interactions between the mycotoxins deoxynivalenol, nivalenol and their acetyl derivatives in intestinal epithelial cells. Archives of Toxicology 89: 1337-1346.

Alassane-Kpembi, I., Puel, O., Pinton, P., Cossalter, A.-M., Chou, T.C. and Oswald, I.P., 2017. Co-exposure to low doses of the food contaminants deoxynivalenol and nivalenol has a synergistic inflammatory effect on intestinal explants. Archives of Toxicology 91: 2677-2687.

Allen, R.G. and Tressini, M., 2000. Oxidative stress and gene regulation. Free Radical Biology and Medicine 28: 463-499.

Alm-Eldeen, A.A., Mona, M.H., Shati, A.A. and El-Mekkawy, H.I., 2015. Synergistic effect of black tea and curcumin in improving the hepatotoxicity induced by aflatoxin $B_{1}$ in rats. Toxicology and Industrial Health 31: 1269-1280.

Alpsoy, L., Yildrim, A. and Agar, G., 2009. The antioxidant effects of vitamin $\mathrm{A}, \mathrm{C}$, and $\mathrm{E}$ on aflatoxin $\mathrm{B}_{1}$-induced oxidative stress in human lymphocytes. Toxicology and Industrial Health 25: 121-127.

An, Y., Shi, X., Tang, X., Wan, Y., Shen, F., Zhang, Q., Wang, C., Jiang, M., Liu, M. and Yu, L., 2017. Aflatoxin $B_{1}$ induces reactive oxygen species-mediated autophagy and extracellular trap formation in macrophages. Frontiers in Cellular and Infection Microbiology 7: 53.

Anuradha, C.D., Kanno, S. and Hirano, S., 2001. Oxidative damage to mitochondria is a preliminary step to caspase- 3 activation in fluoride-induced apoptosis in HL-60 cells. Free Radical Biology and Medicine 31: 367-373.

Assi, M., 2017. The differential role of reactive oxygen species in early and late stages of cancer. American Journal of Physiology Regulatory, Integrative and Comparative Physiology 313: R646-R653.

Assunção, R., Alivto, P., Kleiveland, C.R. and Lea, T.E., 2016. Characterization of in vitro effects of patulin on intestinal epithelial and immune cells. Toxicology Letters 27: 250-251.

Atroshi, F., Biese, I., Saloniemi, H., Ali-Vehmas, T., Saari, S., Rizzo, A. and Veijalainen, P., 2000a. Significance of apoptosis and its relationship to antioxidants after ochratoxin A administration in mice. Journal of Pharmacy and Pharmaceutical Sciences 3: 281-291.

Atroshi, F., Rizzo, A., Biese, I., Lindberg, L.A. and Saloniemi, H., 1995. Effects of feeding T-2 toxin and deoxynivalenol on DNA and GSH contents of brain and spleen of rats supplemented with vitamin $\mathrm{E}$ and $C$ and selenium combination. Journal of Animal Physiology and Animal Nutrition 74: 157-164.

Atroshi, F., Rizzo, A., Biese, I., Veijalainen, P., Antila, E. and Westermarck, T., 1997. T-2 toxin-induced DNA damage in mouse livers: the effect of pretreatment with coenzyme Q10 and alphatocopherol. Molecular Aspects of Medicine 18: S255-S258.

Atroshi, F., Rizzo, A., Biese, I., Veijalainen, P., Saloniemi, H., Sankari, S. and Andersson, K., 1999. Fumonisin $B_{1}$-induced DNA damage in rat liver and spleen: effects of pretreatment with coenzyme Q10, L-carnitine, alpha-tocopherol and selenium. Pharmacology Research 40: 459-467. 
Atroshi, F., Rizzo, A., Sankari, S., Biese, I., Westermarck, T. and Veijalainen, P., 2000. Liver enzyme activities of rats exposed to ochratoxin A and T-2 toxin with antioxidants. Bulletin of Environmental Contamination and Toxicology 64: 586-592.

Aydin, G., Ozçelik, N., Ciçek, E. and Soyöz, M., 2003. Histopathologic changes in liver and renal tissues induced by ochratoxin $\mathrm{A}$ and melatonin in rats. Human and Experimental Toxicology 22: 383-391.

Aydin, S., Palabiyik, S.S., Erkekoglu, P., Sahin, G., Başaran, N. and Giray, B.K., 2013. The carotenoid lycopene protects rats against DNA damage induced by Ochratoxin A. Toxicon. 73: 96-103.

Ayed-Boussema, I., Abassi, H., Bouaziz, C., Hlima, W.B., Ayed, Y. and Bacha, H., 2013. Antioxidative and antigenotoxic effect of vitamin E against patulin cytotoxicity and genotoxicity in HepG2 cells. Environmental Toxicology 28: 299-306.

Ben Salem, I., Boussabbeh, M., Helali, S., Abid-Essefi, S. and Bacha, H., 2015a. Protective effect of crocin against zearalenone-induced oxidative stress in liver and kidney of Balb/c mice. Environmental Science and Pollution Research International 22: 19069-19076.

Ben Salem, I., Prola, A., Boussabbeh, M., Guilbert, A., Bacha, H., Abid-Essefi, S. and Lemaire, C., 2015b. Crocin and quercetin protect HCT116 and HEK293 cells from zearalenone-induced apoptosis by reducing endoplasmic reticulum stress. Cell Stress Chaperones 20: 927-938.

Bennett, J.W. and Klich, M., 2003. Mycotoxins. Clinical Microbiology Reviews 16: 497-516.

Bergendi, L., Benes, L., Durackova, Z. and Ferencik, M., 1999. Chemistry, physiology and pathology of free radicals. Life Science 65: 1865-1874.

Bhat, P.V., Pandareesh, M.D., Khanum, F. and Tamatam, A., 2016. Cytotoxic effects of ochratoxin A in neuro-2a cells: role of oxidative stress evidenced by $\mathrm{N}$-acetylcysteine. Frontiers in Microbiology 7: 1142 .

Birben, E., Sahiner, U.M., Sackese, C., Erzurum, S. and Kalayci, O., 2012. Oxidative stress and antioxidant defense. World Allergy Organisation Journal 5: 9-19.

Boeira, S.P., Funck, V.R., Borges Filho, C., Del'Fabbro, L., de Gomes, M.G., Donato, F., Royes, L.F., Oliveira, M.S., Jesse, C.R. and Furian, A.F., 2015. Lycopene protects against acute zearalenone-induced oxidative, endocrine, inflammatory and reproductive damages in male mice. Chemico-Biological Interactions. 230: 50-57.

Borutova, R., Faix, S., Placha, I., Gresakova, L., Cobanova, K. and Leng, L., 2008. Effects of deoxynivalenol and zearalenone on oxidative stress and blood phagocytic activity in broilers. Archives of Animal Nutrition 62: 303-312.

Boussabbeh, M., Ben Salem, I., Belquesmi, F., Bacha, H. and AbidEssefi, S., 2016a. Tissue oxidative stress induced by patulin and protective effect of crocin. Neurotoxicolgy 53: 343-349.

Boussabbeh, M., Ben Salem, I., Belquesmi, F., Neffati, F., Najjar, M.F., Abi-Essefi, S. and Bacha, H., 2016b. Crocin protects the liver and kidney from patulin-induced apoptosis in vivo. Environmental Science and Pollution Research International 23: 9799-9808.

Boussabbeh, M., Ben Salem, I., Neffati, F., Najjar, M., Bacha, M. and Abid-Essefi, S., 2015. Crocin prevents patulin-induced acute toxicity in cardiac tissues via the regulation of oxidative damage and apoptosis. Journal of Biochemical and Molecular Toxicology 29: 479-488.
Cano, P., Seeboth, J., Meurens, F., Cognie, J., Abrami, R., Oswald, I.P. and Guzylack-Piriou, L., 2013. Deoxynivalenol as a new factor in the persistence of intestinal inflammatory diseases: an emerging hypothesis through possible modulation of Th17-mediated response. PLoS ONE 8: e53647.

Capcarova, M., Petruska, P., Zbynovska, K., Kolesarova, A. and Sirotkin, A.V., 2015. Changes in antioxidant status of porcine ovarian granulosa cells after quercetin and T-2 toxin treatment. Journal of Environmental Science and Health, Part B 50: 201-206.

Cassand, P., Decoudu, S., Levegue, F., Daubeze, M. and Narbonne, J.F., 1993. Effect of vitamin $\mathrm{E}$ dietary intake on in vitro activation of aflatoxin $B_{1}$. Mutation Research. 319: 309-316.

Chaudhari, M., Lakshmana, R.P.V., 2010. Brain oxidative stress after dermal and subcutaneous exposure of T-2 toxin in mice. Food and Chemical Toxicology 48: 3436-3442.

Cheat, S., Gerez, J.R., Cognie, J., Alassane-Kpembi, I., Bracarense, A.P.F.L., Raymond-Letron, I., Oswald, I.P. and Kolf-Clauw, M., 2015. Nivalenol has a greater impact than deoxynivalenol on pig jejunum mucosa in vitro on explants and in vivo on intestinal loops. Toxins 7: 1945-1961.

Chen, J.H., Cao, J.L., Chu, Y.L., Wang, Z.L., Yang, Z.T. and Wang, H.-L., 2008. T-2 toxin-induced apoptosis involved Fas, p53, Bcl-xL, Bcl2 , Bax and caspase-3 signaling pathways in human chondrocytes. Journal of Zhejiang University Science B9: 455-463.

Choi, K.C., Chung, W.T., Kwon, J.K., Yu, J.Y., Jang, Y.S., Park, S.M., Lee, S.Y. and Lee, J.C., 2010. Inhibitory effects of quercetin on aflatoxin $\mathrm{B}_{1}$-induced hepatic damage in mice. Food and Chemical Toxicology 48: 2747-2753.

Citil, M., Gunes, V., Atakisi, O., Ozcan, A., Tuzcu, M. and Dogan, A., 2005. Protective effect of $\mathrm{L}$-carnitine against oxidative damage caused by experimental chronic aflatoxicosis in quail (Coturnix coturnix). Acta Veterinaria Hungarica 53: 319-324.

Cooper, R., Morre, D.J. and Morre, D.M., 2005. Medicinal benefits of green tea: Part I. Review of non-cancer health benefits. Journal of Alternative and Complementary Medicine 11: 521-528.

Corcuera, L.A., Amezqueta, S., Arbillaga, L., Vettorazzi, A., Tourino, S., Torres, J.L. and Lopez de Cerain, A., 2012. A polyphenol-enriched cocoa extract reduces free radicals produced by mycotoxins. Food and Chemical Toxicology 50: 989-995.

Costa, J.G., Saraiva, N., Guerreiro, P.S., Louro, H., Silva, M.J., Miranda, J.P., Castro, M., Batinic-Haberle, I., Fernandes, A.S. and Oliveira, N.G., 2016. Ochratoxin A-induced cytotoxicity, genotoxicity and reactive oxygen species in kidney cells: an integrative approach of complementary endpoints. Food and Chemical Toxicology 87: 65-76.

Costa, S., Utan, A., Cervellati, R., Speroni, E. and Guerra, M.C., 2007. Catechins: natural free-radical scavengers against ochratoxin A-induced cell damage in a pig kidney cell line (LLC-PK1). Food and Chemical Toxicology 45: 1910-1917.

Dalle-Donne, I., Rossi, R., Colombo, R., Giustarini, D. and Milzani, A., 2006. Biomarkers of oxidative damage in human disease. Clinical Chemistry 52: 601-623.

Del Regno, M., Adesso, S., Popolo, A., Quaroni, A., Autore, G., Severino, L. and Marzocco, S., 2015. Nivalenol induces oxidatve stress and increases deoxynivalenol pro-oxidant effect in intestinal epithelial cells. Toxicology and Applied Pharmacology 285: 118-127. 
Diplock, A.T., Charleux, J.L., Grozier-Willi, G., Kok, F.J., Rice-Evans, C. and Roberfroid, M., 1998. Functional food science and defence against reactive oxidative species. British Journal of Nutrition 80, Suppl. 1: S77-S112.

Domijan, A.M. and Abramov, A.Y., 2011. Fumonisin $B_{1}$ inhibits mitochondrial respiration and deregulates calcium homeostasis implication to mechanism of cell toxicity. International Journal of Biochemistry and Cell Biology 43: 897-904.

Domijan, A.M., Gajski, G., Jovanovic, I.N., Geric, M. and GarajVrhovac, V., 2015. In vitro genotoxicity of mycotoxin ochratoxin $A$ and fumonisin $B_{1}$ could be prevented by sodium copper chlorophylin-implication to their genotoxic mechanism. Food Chemistry 170: 455-462.

Domijan, A.M., Peraica, M., Vrdoljak, A.L., Radić, B., Zlender, V. and Fuchs, R., 2007. The involvement of oxidative stress in ochratoxin $A$ and fumonisin $B_{1}$ toxicity in rats. Molecular Nutrition and Food Research 51: 1147.

Douarre, C., Sourbier, C., Dalla Rosa, I., Brata Das, B., Redon, C.E., Zhnag, H., Neckers, L. and Pommier, Y., 2012. Mitochondrial topoisomerase I is critical for mitochondrial integrity and cellular energy metabolism. PLoS ONE 7: e41094.

Droge, W., 2002. Free radicals in the physiological control of cell function. Physiology Review 82: 47-95.

El Golli, E., Hassen, W., Bouslimi, A., Bouaziz, C., Ladjimi, M.M. and Bacha, H., 2006. Induction of Hsp 70 in Vero cells in response to mycotoxins cytoprotection by sub-lethal heat shock and by vitamin E. Toxicology Letters 166: 122-130.

El-Bahr, S.M., 2015. Effect of curcumin on hepatic antioxidant enzymes activities and gene expressions in rats intoxicated with aflatoxin $B_{1}$. Phytotherapy Research 29: 134-140.

El-Barbary, M.I., 2016. Detoxification and antioxidant effects of garlic and curcumin in Oreochromis niloticus injected with aflatoxin $\mathrm{B}_{1}$ with reference to gene expression of glutathione peroxidase (GPx) by RT-PCR. Fish Physiology and Biochemistry 42: 617-629.

Fan, W., Shen, T., Ding, Q., Lv, Y., Li, L., Huang, K. and Yan, L., 2017. Zearalenone induces ROS-mediated mitochondrial damage in porcine IPEC-J2 cells. Journal of Biochemical and Molecular Toxicology 31: e21944.

Farley, N., Pedraza-Alva, G., Serrano-Gomez, D., Nagaleekar, V., Aronshtam, A., Krahl, T., Thornton, T. and Rincon, M., 2006. P38 mitogen-activated protein kinase mediates the fas-induced mitochondrial death pathway in CD8 ${ }^{+} \mathrm{T}$ cells. Molecular and Cellular Biology 26: 2118-2129.

Frankic, T., Salobir, J. and Rezar, V., 2008. The effect of vitamin E supplementation on reduction of lymphocyte DNA damage induced by T-2 toxin and deoxynivalenol in weaned pigs. Animal Feed Science and Technology 141: 274-286.

Frizzell, C., Ndossi, D., Verhaegen, S., Dahl, E., Eriksen, G., Sorlie, M., Ropstad, E., Muller, M., Elliott, C.T. and Connolly, L., 2011. Endocrine disrupting effects of zearalenone, alpha- and beta-zearalenol at the level of nuclear receptor binding and steroidogenesis. Toxicology Letters 206: 210-217.

Fusi, E., Rebucci, R., Pecorini, C., Campagnoli, A., Pinotti, L., Saccone, F., Cheli, F., Purup, S., Sejrsen, K. and Baldi, A., 2010. Alphatocopherol counteracts the cytotoxicity induced by ochratoxin a in primary porcine fibroblasts. Toxins 2: 1265-1278.
Galvano, F., Russo, A., Cardile, V., Galvano, G., Vanella, A. and Renis, M., 2002. DNA damage in human fibroblasts exposed to fumonisin $B_{1}$. Food and Chemical Toxicology 40: 25-31.

Gan, F., Hou, L., Zhou, Y., Liu, Y., Huang, D., Chen, X. and Huang, K., 2017. Effect of ochratoxin A on ER stress, MAPK signaling pathway and autophagy of kidney and spleen in pigs. Environmental Toxicology 32: 2277-2286.

Gayathri, L., Dhivya, R., Dhanasekaran, D., Periasamy, V.S., Alshatwi, A.A. and Akbarsha, M.A., 2015. Hepatotoxic effect of ochratoxin $A$ and citrinin, alone and in combination, and protective effect of vitamin E: in vitro study in HepG2 cell. Food and Chemical Toxicology 83: 151-163.

Ghedira-Chekir, L., Maaroufi, K., Zakhama, A., Ellouz, F., Dhouib, S., Creppy, E.E. and Bacha, H., 1998. Induction of a SOS repair system in lysogenic bacteria by zearalenone and its prevention by vitamin E. Chemico-Biological Interactions 113: 15-25.

Gowda, N.K., Ledoux, D.R., Rottinghaus, G.E., Bermudez, A.J. and Chen, Y.C., 2009. Antioxidant efficacy of curcuminoids from turmeric (Curcuma longa L.) powder in broiler chickens fed diets containing aflatoxin $B_{1}$. British Journal of Nutrition 102: 1629-1634.

Gradelet, S., Le Bon, A.M., Bergès, R., Suschetet, M. and Astorg, P., 1998. Dietary carotenoids inhibit aflatoxin B1-induced liver preneoplastic foci and DNA damage in the rat: role of the modulation of aflatoxin B1 metabolism. Carcinogenesis. 19: 403-411.

Graziani, F., Pujol, A., Nicoletti, C., Pinton, P., Armand, L., Di Pasquale, E., Oswald, I.P., Perrier, J. and Maresca, M., 2015. The food-associated ribotoxin deoxynivalenol modulates the expression of the inducible NO synthase by the human intestinal epithelium. Toxicological Science 145: 372-382.

Grenier, B., Bracarense, A.P., Schwartz, H.E., Trumel, C., Cossalter, A.M., Schatzmayr, G., Kolf-Clauw, M., Moll, W.D. and Oswald, I.P., 2012. The low intestinal and hepatic toxicity of hydrolyzed fumonisin $\mathrm{B}_{1}$ correlates with its inability to alter the metabolism of sphingolipids. Biochemical Pharmacology 83: 1465-1473.

Grosse, Y., Chekir-Ghedira, L., Huc, A., Obrecht-Pflumio, S., Dirheimer, G., Bacha, H. and Pfohl-Leszkowicz, A., 1997. Retinol, ascorbic acid and $\alpha$-tocopherol prevent DNA adduct formation in mice treated with the mycotoxins ochratoxin A and zearalenone. Cancer Letters 114: 225-229.

Gross-Steinmeyer, K., Stapleton, P.L., Tracy, J.H., Bammler, T.K., Strom, S.C., Buhler, D.R. and Eaton, D.L., 2009. Modulation of aflatoxin $\mathrm{B}_{1}$-mediated genotoxicity in primary cultures of human hepatocytes by diindolylmethane, curcumin, and xanthohumols. Toxicological Science 112: 303-310.

Guo, C., Sun, L., Chen, X. and Zhang, D., 2013. Oxidative stress, mitochondrial damage and neurodegenerative diseases. Neural Regeneration Research 8: 2003-2014.

Halliwell, B. and Whiteman, M., 2004. Measuring reactive species and oxidative damage in vivo and in cell culture: how should you do it and what do the results mean? British Journal of Pharmacology 142: 231-255.

Hassan, A.M., Abdel-Aziem, S.H., El-Nekeety, A.A. and AbdelWahhab, M.A., 2015. Panax ginseng extract modulates oxidative stress, DNA fragmentation and up-regulate gene expression in rats subcronically treated with aflatoxin B and fumonisin B. Cytotechnology 67: 861-871. 
Hassen, W., Ayed-Boussema, I., Oscoz, A.A., Lopez De Cerain, A. and Bacha, H., 2007. The role of oxidative stress in zearalenone-mediated toxicity in Hep G2 cells: oxidative DNA damage, gluthatione depletion and stress proteins induction. Toxicology 232: 294-302.

Hayes, J. and Strange, R., 1995. Potential contribution of the glutathione S-transferase supergene family to resistance to oxidative stress. Free Radical Research 22: 193-207.

Hoehler, D. and Marquardt, R.R., 1996. Influence of vitamins E and C on the toxic effects of ochratoxin A and T-2 toxin in chicks. Poultry Science 75: 1508-1515.

Hou, Y.J., Zhao, Y.Y., Xiong, B., Cui, X.S., Kim, N.H., Xu, Y.X. and Sun, S.C., 2013. Mycotoxin-containing diet causes oxidative stress in the mouse. PLoS One 8: e60374.

Ismaiel, A.A.M., El-Denshary, E.S., El-Nekeety, A.A., Al-Yamani, A.F., Gad, S.A., Hassan, N.S. and Abdel-Wahhab, M.A., 2015. Ameliorative effects of curcumin nanoparticles on hepatotoxicity induced by zearalenone mycotoxin. Global Journal of Pharmacology 9: 234-245.

Jaradat, Z.W., Viia, B. and Marquardt, R.R., 2006. Adverse effects of $\mathrm{T}-2$ toxin on chicken lymphocytes blastogenesis and its protection with vitamin E. Toxicology 225: 90-96.

Jayashree, G.V., Krupashree, K., Rachitha, P. and Khanum, F., 2017. Patulin induced oxidative stress mediated apoptotic damage in mice, and its modulation by green tea leaves. Journal of Clinical and Experimental Hepatology 7: 127-134.

Jin, H., Yin, S., Song, X., Zhang, E., Fan, L. and Hu, H., 2016. P53 activation contributes to patulin-induced nephrotoxicity via modulation of reactive oxygen species generation. Scientific Reports 6: 24455 .

Jin, J., Xiong, T., Hou, X., Sun, X., Liao, J., Huang, Z., Huang, M. and Zhao, Z., 2014. Role of Nrf2 activation and NF- $\mathrm{kB}$ inhibition in valproic acid induced hepatotoxicity and in diammonium glycyrrhizinate induced protection in mice. Food and Chemical Toxicology 73: 95-104.

Kim, I., Xu, W. and Reed, J.C., 2008. Cell death and endoplasmic reticulum stress: disease relevance and therapeutic opportunities. Nature Reviews Drug Discovery 7: 1013-1030.

Koraichi, F., Videmann, B., Mazallon, M., Benahmed, M., Prouillac, C. and Lecoeur, S., 2012. Zearalenone exposure modulates the expression of $\mathrm{ABC}$ transporters and nuclear receptors in pregnant rats and fetal liver. Toxicology Letters 211: 246-256.

Kouadio, J.H., Mobio, T.A., Baudrimont, I., Moukaha, S., Dano S.D. and Creppy, E.E., 2005. Comparative study of cytotoxicity and oxidative stress induced by deoxynivalenol, zearalenone or fumonisin $B_{1}$ in human intestinal cell line Caco-2. Toxicology 213: 56-65.

Kumar, P., Mahato, D.K., Kamlel, M., Mohanta, T.K. and Kang, S.G., 2017. Aflatoxins: a global concern for food safety, human health and their management. Frontiers in Microbiology 7: 2170.

Lallès, J.P., Lessard, M., Oswald, I.P. and David, J.C., 2010. Consumption of fumonisin $B_{1}$ for 9 days induces stress proteins along the gastrointestinal tract of pigs. Toxicon 55: 244-249.

Lautert, C., Ferreiro, L., Wolkmer, P., Paim, F.C., Da Silva, C.B., Jaques, J.A., Lopes, S.T. and Santurio, J.M., 2014. Individual in vitro effects of ochratoxin A, deoxynivalenol and zearalenone on oxidative stress and acetylcholinesterase in lymphocytes of broiler chickens. Springerplus 3: 506 .
Leal, M., Shimada, A., Ruiz, F. and Gonzalez de Mejia, E., 1999. Effect of lycopene on lipid peroxidation and glutathione-dependent enzymes induced by T-2 toxin in vivo. Toxicology Letters 209: 1-10.

Li, D., Ye, Y., Lin, S., Deng, L., Fan, X., Zhang, Y., Deng, X., Li, Y., Yan., H. and Ma, H.Y., 2014. Evaluation of deoxynivalenol-induced toxic effects on DF-1 cells in vitro: cell cycle arrest, oxidative stress, and apoptosis. Environmental Toxicology and Pharmacology 37: 141-149.

Li, M. and Pestka, J.J., 2008. Comparative induction of $28 \mathrm{~S}$ ribosomal RNA cleavage by ricin and the trichothecenes deoxynivalenol and T-2 toxin in the macrophage. Toxicological Science 105: 67-78.

Li, X., Gao, J., Huang, K., Qi, X., Dai, Q., Mei, X. and Xu, W., 2015. Dynamic changes of global DNA methylation and hypermethylation of cell adhesion-related genes in rat kidneys in response to ochratoxin A. World Mycotoxin Journal 8: 465-476.

Li, Y., Wang, Z., Beier, R.C., De Shen, J., De Smet, D., De Saeger, S. and Zhang, S., 2011. T-2 toxin, a trichothecene mycotoxins: review of toxicity, metabolism, and analytical methods. Journal of Agricultural and Food Chemistry 59: 3441-3453.

Limonciel, A. and Jennings, P., 2014. A review of the evidence that ochratoxin A is an Nrf2 inhibitor: implications for nephrotoxicity and renal carcinogenicity. Toxins 6: 371-379.

Lin, J.K. and Wang, C.J., 1986. Protection of crocin dyes on the acute hepatic damage induced by aflatoxin $B_{1}$ and dimethylnitrosamine in rats. Carcinogenesis 7: 595-599.

Liu, M., Zhu, D., Guo, T., Zhang, Y., Shi, B., Shan, A. and Chen, Z., 2018. Toxicity of zearalenone on the intestines of pregnant sows and their offspring and alleviation with modified halloysite nanotubes. Journal of the Science and Food Agriculture 98: 698-706.

Liu, Y. and Wang, W.J., 2016. Aflatoxin $\mathrm{B}_{1}$ impairs mitochondrial functions, activates ROS generation, induces apoptosis, and involves in Nrf2 signal pathway in primary broiler hepatocytes. Animal Science Journal 87: 1490-1500.

Loiseau, N., Debrauwer, L., Sambou, T., Bouhet, S., Miller, J.D., Martin, P., Viadère, J.L., Pinton, P., Puel, O., Pineau, T., Tulliez, J., Galtier, P. and Oswald, I.P., 2007. Fumonisin $B_{1}$ exposure and its selective effect on porcine jenunal segment: sphingolipids, glycolipids and transepithelial-passage disturbance. Biochemical Pharmacology 74: 144-152.

Long, M., Yang, S., Wang, Y., Li, P., Zhang, Y., Dong, S., Chen, X., Guo, J., He, J., Gao, Z. and Wang, J., 2016a. The protective effect of selenium on chronic zearalenone-induced reproductive system damage in male mice. Molecules 21: E1687.

Long, M., Yang, S., Zhang, Y., Li, P., Han, J., Dong, S., Chen, X. and He, J., 2016b. Proanthocyanidin protects against acute zearalenoneinduced testicular oxidative damage in male mice. Environmental Science and Pollution Research International 24: 938-946.

Long, M., Zhang, Y., Li, P., Yang, S.H., Zhang, W.K., Han, J.X., Wang, Y. and He, J.B., 2016c. Intervention of grape seed proanthocyanidin extract on the subchronic immune injury in mice induced by aflatoxin $\mathrm{B}_{1}$. International Journal of Molecular Science 17: 516.

Lu, X., Zhang, E., Yin, S., Fan, L. and Hu, H., 2017. Methylseleninic acid prevents patulin-induced hepatotoxicity and nephrotoxicity via the inhibition of oxidative stress and inactivation of p53 and MAPKs. Journal of Agricultural and Food Chemistry 65: 5299-5305. 
Ma, Q., Li, Y., Fan, Y., Zhao, L., Wei, H., Ji, C. and Zhang, J., 2015. Molecular mechanisms of lipoic acid protection against aflatoxin B1-induced liver oxidative damage and inflammatory responses in broilers. Toxins 7: 5435-5447.

Maidana, L., Gerez, J.R., El Khoury, R., Pinho, F., Puel, O., Oswald, I.P. and Bracarense, A.P.F.R.L., 2016. Effects of patulin and ascladiol on porcine intestinal mucosa: an ex vivo approach. Food and Chemical Toxicology 98: 189-194.

Maki, A., Berezesky, I.K., Fargnoli, J., Holbrook, N.J. and Trump, B.F., 1992. Role of $\mathrm{Ca}^{2+}$ in induction of c-fos, c-jun, and c-myc mRNA in rat PTE after oxidative stress. FASEB Journal 6: 919-924.

Malir, F., Ostry, V., Pfohl-Leszkowicz, A., Malir, J. and Toman, J., 2016. Ochratoxin A: 50 years of research. Toxins 8: 191.

Mally, A. and Dekant, W., 2009. Mycotoxins and the kidney: modes of action for renal tumor formation by ochratoxin A in rodents. Molecular Nutrition and Food Research 53: 467-478.

Maresca, M., 2013. From the gut to the brain: journey and pathophysiological effects of the food-associated trichothecene mycotoxin deoxynivalenol. Toxins 5: 784-820.

Marin, D.E., Pistol, G.C., Neagoe, I.V., Calin, L. and Taranu, I., 2015. Effects of zearalenone on oxidative stress and inflammation in weanling piglets. Food and Chemical Toxicology 58: 408-415.

Marnett, L.J., 1999. Lipid peroxidation-DNA damage by malondialdehyde. Mutation Research - Fundamental and Molecular Mechanisms of Mutagenesis 424: 83-95.

Marnewick, J.L., Van der Westhuizen, F.H., Joubert, E., Swanevelder, S., Swart, P. and Gelderblom, W.C., 2009. Chemoprotective properties of rooibos (Aspalathus linearis), honeybush (Cyclopia intermedia) herbal and green and black (Camellia sinensis) teas against cancer promotion induced by fumonisin $\mathrm{B}_{1}$ in rat liver. Food and Chemical Toxicology. 47: 220-229.

Mary, V.S., Arias, S.L., Otaiza, S.N., Velez, P.A., Rubinstein, H.R. and Theumer, M.G., 2017. The aflatoxin $B_{1}$-fumonin $B_{1}$ toxicity in BRL-3A hepatocytes is associated to induction of cytochrome P450 activity and arachidonic acid metabolism. Environmental Toxicology 32: 1711-1724.

Mary, V.S., Theumer, M.G., Arias, S.L. and Rubinstein, H.R., 2012. Reactive oxygen species sources and biomolecular oxidative damage induced by aflatoxin $B_{1}$ and fumonisin $B_{1}$ in rat spleen mononuclear cells. Toxicology 302: 299-307.

Marzocco, S., Russo, R., Bianco, G., Autore, G. and Severino, L., 2009. Pro-apoptotic effects of nivalenol and deoxynivalenol trichothecenes in J774A.1 murine macrophages. Toxicology Letters 89: 21-26.

Mathuria, N. and Verma R.J., 2007a. Ameliorative effect of curcumin on aflatoxin-induced toxicity in DNA, RNA and protein in liver and kidney of mice. Acta Poloniae Phamaceutica 64: 497-502.

Mathuria, N. and Verma, R.J., 2007b. Curcumin ameliorates aflatoxininduced lipid peroxidation in liver, kidney and testis of mice-an in vitro study. Acta Poloniae Phamaceutica 64: 413-416.

Maurya, B.K. and Trigun, S.K., 2016. Fisetin modulates antioxidant enzymes and inflammatory factors to inhibit aflatoxin $B_{1}$ induced hepatocellular carcinoma in rats. Oxidative Medicine and Cellular Longevity 2016: 1972793.
Meissonnier, G.M., Laffitte, J., Loiseau, N., Benoit, E., Raymond, I., Pinton, P., Cossalter, A.M., Bertin, G., Oswald I.P. and Galtier P., 2007. Selective impairment of drug-metabolizing enzymes in pig liver during subchronic dietary exposure to aflatoxin $B_{1}$. Food and Chemical Toxicology 45: 2145-2154.

Meissonnier, G.M., Laffitte, J., Raymond, I., Benoit, E., Cossalter, A.M., Pinton, P., Bertin, G., Oswald, I.P. and Galtier, P., 2008. Subclinical doses of T-2 toxin impair acquired immune response and liver cytochrome P450 in pigs. Toxicology 247: 46-54.

Meki, A.R., Abdel-Ghaffar, S.K. and El-Gibaly, I., 2001. Aflatoxin $B_{1}$ induces apoptosis in rat liver: protective effect of melatonin. Neuroendocrinology Letters 22: 417-426.

Meki, A.R., Esmail Eel, D., Hussein, A.A. and Hassanein, H.M., 2004. Caspase- 3 and heat shock protein-70 in rat liver treated with aflatoxin $B_{1}$ : effect of melatonin. Toxicon 43: 93-100

Minasyan, L., Sreekumar, P.G., Hinton, D.R. and Kannan, R., 2017. Protective mechanisms of the mitochondrial-derived peptide human in in oxidative and endoplasmic reticulum stress in RPE cells. Oxidative Medicine and Cellular Longevity 2017: 1675230.

Moosavi, M., Rezaei, M., Kalantari, H., Behfar, A. and Varnaseri, G., 2016. L-carnitine protects rat hepatocytes from oxidative stress induced by T-2 toxin. Drug and Chemical Toxicology 39: 445-450.

Mordente, A., Guantario, B., Meucci, E., Silvestrini, A., Lombardi, E., Martorana, G.E., Giardina, B. and Bohm, V., 2011. Lycopene and cardiovascular diseases: an update. Current Medicinal Chemistry 18: 1146-1163.

Nayak, S. and Sashidhar, R.B., 2010. Metabolic intervention of aflatoxin $B_{1}$ toxicity by curcumin. Journal of Ethnopharmacology 127: 641-644.

Netke, S. P., Roomi, M.W., Tsao, C. and Niedzwiecki, A., 1997. Ascorbic acid protects guinea pigs from acute aflatoxin toxicity. Toxicology and Applied Pharmacology. 143: 429-435.

Nones, J., Nones, J. and Trentin, A.G., 2013. Flavonoid hesperidin protects neural crest cells from death caused by aflatoxin $\mathrm{B}_{1}$. Cell Biology International 37: 181-186.

Oskoueian, E., Abdullah, N., Zulkifli, I., Ebrahimi, M., Karimi, E., Goh, Y.M., Oskoueian, A. and Shakeri, M., 2015. Cytoprotective effect of palm kernel cake phenolics against aflatoxin $\mathrm{B}_{1}$-induced cell damage and its underlying mechanism of action. BMC Complementary and Alternative Medicine 15: 392.

Osselaere, A., Santos, R., Hautekiet, V., Backer, P.D., Chiers, K., Ducatelle, R. and Croubels, S., 2013. Deoxynivalenol impairs hepatic and intestinal gene expression of selected oxidative stress, tight junction and inflammation proteins in broiler chickens, but addition of an adsorbing agent shifts the effects to the distal parts of the small intestine. PLoS ONE 8: e69014.

Pacheco, G.D., Silva, C.A., Pinton, P., Oswald, I.P. and Bracarense, A.P., 2012. Phytic acid protects porcine intestinal epithelial cells from deoxynivalenol (DON) cytotoxicity. Experimental Toxicology Pathology 64: 345-347.

Parveen, M., Zhu, Y. and Kiyama, R., 2009. Expression profiling of the genes responding to zearalenone and its analogues using estrogenresponsive genes. FEBS Letters 583: 2377-2384.

Payros, D., Alassane-Kpembi, I., Pierron, A., Loiseau, N., Pinton, P. and Oswald, I.P., 2016. Toxicology of deoxynivalenol and its acetylated and modified forms. Archives of Toxicology 90: 2931-2957. 
Pestka, J.J., 2008. Mechanisms of deoxynivalenol-induced gene expression and apoptosis. Food Additives and Contaminants, Part A $25: 1128-1140$.

Pestka, J.J., 2010a. Deoxynivalenol mechanism of action, human exposure, and toxicological relevance. Archives of Toxicology 84: 663-679.

Pestka, J.J., 2010b. Deoxynivalenol-induced proinflammatory gene expression: mechanisms and pathological squelae. Toxins 2: $1300-1317$.

Pickett, C.B. and Lu, A.Y.H., 1989. Glutathione S-transferases: gene structure, regulation, and biological activity. Annual Review of Biochemistry 58: 743-764.

Pierron, A., Mimoun, S., Murate, L.S., Loiseau, N., Lippi, Y., Bracarense, A.P.F.L., Schatzmayr, G., He, J., Zhou, T., Moll, W.D. and Oswald, I.P., 2016. Microbial biotransformation of DON: molecular basis for reduced toxicity. Scientific Reports 6: 29105.

Placha, I., Borutova, R., Gresakova, L., Petrovic, V., Faix, S. and Leng, L., 2009. Effects of excessive selenium supplementation to diet contaminated with deoxynivalenol on blood phagocytic activity and antioxidative status of broilers. Journal of Animal Physiology and Animal Nutrition 93: 695-702.

Poapolathep, S., Imsilp, K., Machii, K., Kumagai, S. and Poapolathep, A., 2015. The effects of curcumin on aflatoxin $B_{1}$-induced toxicity in rats. Biocontrol Science 20: 171-177.

Poersch, A.B., Trombetta, F., Braga, A.C.M., Boeira, S.P., Oliveira, M.S., Dilkin, P., Mallmann, C.A., Fighera, M.R., Royes, L.F.F. and Oliveira, M.S., 2014. Involvement of oxidative stress in subacute toxicity induced by fumonisin $\mathrm{B}_{1}$ in broiler chicks. Veterinary Microbiology 174: 180-185.

Powell, S.R., 2000. The antioxidant properties of zinc. Journal of Nutrition 130: 1447S-1454S

Qian, G., Lu, D., Hu, J., Gan, F., Hou, L., Chen, X. and Huang, K., 2017. Ochratoxin A-induced autophagy in vitro and in vivo promotes porcine circovirus type 2 replication. Cell Death and Disease 8: e2909.

Qin, G., Ning, Y. and Lotlikar, P.D., 2000. Chemoprevention of aflatoxin $\mathrm{B}_{1}$-initiated and carbon tetrachloride-promoted hepatocarcinogenesis in the rat by green tea. Nutrition and Cancer 38: 215-222.

Qin, X., Cao, M., Lai, F., Yang, F.G.W., Zhang, X., Cheng, S., Sun, X., Qin, G., Shen, W. and Li, L., 2015. Oxidative stress induced by zearalenone in porcine granulosa cells and its rescue by curcumin in vitro. PLoS ONE 10: $\mathrm{e} 0127551$.

Ramyaa, P. and Padma, W., 2013. Ochratoxin-induced toxicity, oxidative stress and apoptosis ameliorated by quercetin-modulation of Nrf2. Food and Chemical Toxicology 62: 205-216.

Ramyaa, P., Krishnaswamy, R. and Padma, W., 2014. Quercetin modulates OTA-induced oxidative stress and redox signaling in HepG2 cells-up regulation of Nrf2 expression and down regulation of NF- $\mathrm{kB}$ and Cox-2. Biochemica et Biophysica Acta 1840: 681-692.

Reddy, L., Odhav, B. and Bhoola, K., 2006. Aflatoxin $B_{1}$-induced toxicity in HepG2 cells inhibited by carotenoids: morphology, apoptosis and DNA damage. Biological Chemistry 387: 87-93.

Reiter, R.J., 1997. Aging and oxygen toxicity: relation to changes in melatonin. Age 20: 201-213.
Reuter, S., Gupta, S.C., Chaturvedi, M.M. and Aggarwal, B.B., 2010. Oxidative stress, inflammation, and cancer: how are they linked? Free Radical Biology and Medicine 49: 1603-1616.

Rice-Evans, C. and Miller, N.J., 1996. Antioxidant activities of flavonoids as bioactive components of food. Biochemical Society Transactions 24: 790-795.

Ridnour, L.A., Thomas, D.D., Mancardi, D., Espey, M.G., Miranda, K.M., Paolocci, N., Feelisch, M., Fukutu, J. and Wink, D.A., 2004. The chemistry of nitrosative stress induced by nitric oxide and reactive nitrogen oxide species. Putting perspective on stressful biological situations. Biological Chemistry 385: 1-10.

Rizzo, A.F., Atroshi, F., Hirvi, T. and Saloniemi, H., 1992. The hemolytic activity of deoxynivalenol and T-2 toxin. Natural Toxicology 1 : 106-110.

Rizzo, A.F., Atroshmi, F., Hotupa, A., Sankar, S. and Elovaam, E., 1994. Protective effect of antioxidants against free radical-mediated lipid peroxidation induced by DON or T-2 toxin. Journal of Veterinary Medicine 41: 81-90.

Rock, C.L., Jacob, R.A. and Bowen, P., 1996. Update on the biological characteristics of the antioxidant micronutrients: vitamin $\mathrm{C}$, vitamin $\mathrm{E}$, and the carotenoids. Journal of the American Dietetic Association 96: 693-702.

Rumora, L., Domijan, A.M., Grubisic, T.Z. and Peraica, M., 2007. Mycotoxin fumonisin $B_{1}$ alters cellular redox balance and signalling pathways in rat liver and kidney. Toxicology 242: 31-38.

Sahoo, P.K. and Mukherjee, S.C., 2003. Immunomodulation by dietary vitamin $C$ in healthy and aflatoxin $B_{1}$-induced immunocompromised rohu (Labeo rohita). Comparative Immunology, Microbiology and Infectious Diseases 26: 65-76.

Saini, S.S. and Kaur, A., 2012. Aflatoxin B1: toxicity, characteristics and analysis: mini review. Global Advanced Research Journal of Chemistry and Material Science 1: 63-70.

Salem, I.B., Boussabbeh, M., Neffati, F., Najjar, M.F., Abid-Essefi, S. and Bacha, H., 2016. Zearalenone-induced changes in biochemical parameters, oxidative stress and apoptosis in cardiac tissue: protective role of crocin. Human and Experimental Toxicology 35: 623-634.

Salem, M.H., Kamel, K.I., Yusef, M.I., Hassa, G.A. and El-Nouty, F.D., 2001. Protective role of ascorbic acid to enhance semen quality of rabbits treated with sublethal doses of aflatoxin $\mathrm{B}_{1}$. Toxicology 162: 209-218

Sas, K., Robotka, H., Toldi, J. and Vecsei, L., 2007. Mitochondria, metabolic disturbances, oxidative stress and the kynurenine system, with focus on neurodegenerative disorders. Journal of Neurological Science 257: 221-239.

Sheu, M.L., Shen, C.C., Chen, Y.S. and Chiang, C.K., 2017. Ochratoxin A induces ER stress and apoptosis in mesangial cells via NADPH oxidase-derived reactive oxygen species-mediated calpain activaton pathway. Oncotarget 8: 19376-19388.

Shi, B., Su, Y., Chang, S., Sun, Y., Meng, X. and Shan, A., 2017. Vitamin $C$ protects the piglet liver against zearalenone induced oxidative stress by modulating expression of nuclear receptors PXR and CAR and their target genes. Food and Function. 8: 3675-3687 
Shi, D.Y., Liao, S.Q., Guo, S.N., Li, H., Yang, M.M. and Tang, Z.X., 2015. Protective effects of selenium on aflatoxin $\mathrm{B}_{1}$-induced mitochondrial permeability transition, DNA damage, and histological alterations in duckling liver. Biological Trace Element Research 163: 162-168.

Silva, E.O. and Bracarense, A.P.F.R.L., 2016. Phytic acid: from antinutritional to multiple protection factor of organic systems. Journal of Food Science 81: R135-R1362.

Silva, E.O., Gerez, J.R., Drape, T.C. and Bracarense, A.F.R.L., 2014. Phytic acid decreases deoxynivalenol and fumonisin $B_{1}$-induced changes on swine jejunal explants. Toxicology Reports 1: 284-292.

Sinha, S.P. and Dharmshila, K., 1994. Vitamin A ameliorates the genotoxicity in mice of aflatoxin $\mathrm{B}_{1}$-containing Aspergillus flavus infested food. Cytobios 79: 85-95.

Song, E., Xia, X., Su, C., Dong, W., Xian, Y., Wang, W. and Song, Y., 2014. Hepatotoxicity and genotoxicity of patulin in mice, and its modulation by green tea polyphenols administration. Food and Chemical Toxicology 71: 122-127.

Sorrenti, V., Di Giacomo, C., Acquaviva, R., Barbagallo, I., Bognanno, M. and Galvano, F., 2013. Toxicity of ochratoxin A and its modulation by antioxidants: a review. Toxins 5: 1742-1766.

Sorrenti, V., Di Giacomo, C., Acquaviva, R., Bognanno, M., Grilli, E., D' Orazio, N. and Galvano, F., 2012. Dimethylarginine dimethylaminohydrolase/nitric oxide synthase pathway in liver and kidney: protective effect of cyanidin 3-O- $\beta$-D-glucoside on ochratoxin-A toxicity. Toxins 4: 353-363.

Sozmen, M., Devrim, A.K., Tunca, R., Bayezit, M., Dag, S. and Essiz, D., 2014. Protective effects of silymarin on fumonisin $B_{1}$-induced hepatotoxicity in mice. Journal of Veterinary Science 15: 51-60.

Stockmann-Juvala, H. and Savolainen, K., 2008. A review of the toxic effects and mechanisms of action of fumonisin $B_{1}$. Human and Experimental Toxicology 27: 799-809.

Strasser, A., Carra, M., Ghareeb, K., Awad, W. and Bohm, J,. 2013. Protective effects of antioxidants on deoxynivalenol-induced damage in murine lymphoma cells. Mycotoxin Research 29: 203-208.

Sun, L.H., Lei, M.Y., Zhang, N.Y., Gao, X., Li, C., Krumm, C.S. and Qi, D.S., 2015. Individual and combined cytotoxic effects of aflatoxin $\mathrm{B}_{1}$, zearalenone, deoxynivalenol and fumonisin $\mathrm{B}_{1}$ on BRL $3 \mathrm{~A}$ rat liver cells. Toxicon 95: 6-12.

Sutken, E., Aral, E., Ozdemir, F., Uslu, S., Alatas, O. and Colak, O., 2007. Protective role of melatonin and coenzyme Q10 in ochratoxin A toxicity in rat liver and kidney. International Journal of Toxicology 26: 81-87.

Tanaka, T., Hasegwa-Baba, Y., Watanabe, Y., Mizukami, S., Kangawa, Y., Yoshida, T. and Shibutani, M., 2016. Maternal exposure to ochratoxin A targets intermediate progenitor cells of hippocampal neurogenesis in rat offspring via cholinergic signal downregulation and oxidative stress responses. Reproductive Toxicology 65: 113-122.

Tang, L., Guan, H., Ding, X. and Wang, J.S., 2007. Modulation of aflatoxin toxicity and biomarkers by lycopene in F344 rats. Toxicology and Applied Pharmacology. 219: 10-17.

Tannous, J., Keller, N.P., Atoui, A., Elkhoury, A., Lteif, R., Oswald, I.P. and Puel, O., in press. Secondary metabolism in Penicillium expansum: emphasis on recent advances in patulin research. Critical Reviews in Food Science and Nutrition. DOI: https://doi. org/10.1080/10408398.2017.
Traber, M.G. and Sies, H., 1996. Vitamin E in humans: demand and delivery. Annual Review of Nutrition 16: 321-347.

Tulayakul, P., Dong, K.S., Li, J.Y., Manabe, N. and Kumagai, S., 2007. The effect of feeding piglets with the diet containing green tea extracts or coumarin on in vitro metabolism of aflatoxin $\mathrm{B}_{1}$ by their tissues. Toxicon 50: 339-548.

Ueng, Y.F., Shyu, C.C., Liu, T.Y., Oda, Y., Lin, Y.L., Liao, J.F. and Chen, C.F., 2001. Protective effects of baicalein and wogonin against benzo[a]pyrene- and aflatoxin $\mathrm{B}_{1}$-induced genotoxicities. Biochemical Pharmacology 62: 1653-1660.

Valko, M., Leibfritz, D., Moncol, J., Cronin, M.T.D., Mazur, M. and Telser, J., 2007. Free radicals and antioxidants in normal physiological functions and human disease. International Journal of Biochemistry and Cell Biology 39: 44-84.

Van Houten, B., Woshner, V. and Santos, J.H., 2006. Role of mitochondrial DNA in toxic responses to oxidative stress. DNA Repair 5: 145-152.

Verma, R.J. and Nair, A., 2002. Effect of aflatoxins on testicular steroidogenesis and amelioration by vitamin E. Food and Chemical Toxicology. 40: 669-672.

Verma, R.J. and Mathuria, N., 2008. Curcumin ameliorates aflatoxininduced lipid-peroxidation in liver and kidney of mice. Acta Poloniae Phamaceutica 65: 195-202.

Verma, R.J. and Mathuria, N., 2009. Effect of curcumin on aflatoxininduced biochemical changes in testis of mice. Fertility and Sterility 91: 597-601.

Verma, R.J., Chakraborty, B.S., Patel, C. and Mathuria, N., 2008. Curcumin ameliorates aflatoxin-induced changes in SDH and ATPase activities in liver and kidney of mice. Acta Poloniae Pharmaceutica 65: 415-419.

Voss, K.A., Riley, R.T., Norred, W.P., Bacon, C.W., Filmore, I.M., Howard, P.C., Plattner, R.D., Collins, T.F.X. and Hansen, J.K., 2001. An overview of rodent toxicities: liver and kidney effects of fumonisins and Fusarium moniliform. Environmental Health Perspectives 109, Suppl. 2: 259-266.

Voss, K.A., Smith, G.W. and Hascheck, W.M., 2007. Fumonisins: toxicokinetics, mechanism of action and toxicity. Animal Feed Science and Technology 137: 299-325.

Wang, C.J., Shiow, S.J., Lin, J.K., 1991. Effects of crocetin on the hepatotoxicity and hepatic DNA binding of aflatoxin $B_{1}$ in rats. Carcinogenesis 12: 459-462.

Wang, W.J., Xu, Z.L., Yu, C. and Xu, X.H., 2017. Effects of aflatoxin $\mathrm{B}_{1}$ on mitochondrial respiration, ROS generation and apoptosis in broiler cardiomyocytes. Animal Science Journal 2017: 1561-1567.

Wang, X., Wu, Q., Wan, D., Liu, Q., Chen, D., Liu, Z., MatinezLarranaga, M.R., Martinez, M.A., Anadon, A. and Yuan, Z., 2016. Fumonisins: oxidative stress-mediated toxicity and metabolism in vivo and in vitro. Archives of Toxicology 90: 81-101.

Wang, X., Zuo, Z., Deng, J., Zhang, Z., Chen, C., Fan, Y., Peng, G., Cao, S., Hu, Y., Yu, S., Chen, C. and Ren, Z., in press. Protective role of selenium in immune-relevant cytokine and immunoglobulin production by piglet splenic lymphocytes exposed to deoxynivalenol. Biological Trace Element Research. DOI: https://doi.org/10.1007/ s12011-017-1160-6. 
Wheeler, J.L., Harrison, M.A. and Koehler, P.E., 2006. In vitro metabolism of aflatoxin $B_{1}$ with microsomal enzymes in the presence of selected nutrients. Journal of Food Science 52: 1432-1433.

Wu, F., Groopman, J.D. and Pestka, J.J., 2014a. Public health impacts of foodborne mycotoxins. Annual Review of Food Science and Technology 5: 351-372.

Wu, Q.H., Wang, X., Yang, W., Nüssler, A.K., Xiong, L.Y., Kuca, K., Dohnal, V., Zhang, X.J. and Yuan, Z.H., 2014b. Oxidative stress-mediated cytotoxicity and metabolism of T-2 toxin and deoxynivalenol in animals and humans: an update. Archives of Toxicology 88: 1309-1326.

Xiao, W., Li, S., Wang, S. and Ho, C.T., 2017. Chemistry and bioactivity of Gardenia jasminoides. Journal of Food and Drug Analysis 25: 43-61.

Yang, L., Yu, Z., Hou, J., Deng, Y., Zhou, Z., Zhao, Z. and Cui, J., 2016. Toxicity and oxidative stress induced by T-2 toxin and HT-2 toxin in broilers and broiler hepatocytes. Food and Chemical Toxicology 87: 128-137.

Yang, W., Yu, M., Fu, J., Bao, W., Wang, D., Hao, L., Yao, P., Nussler, A.K., Yan, H. and Liu, L., 2014. Deoxynivalenol induced oxidative stress and genotoxicity in human peripheral blood lymphocytes. Food and Chemical Toxicology 64: 383-396.

Yarru, L.P., Settivari, R.S., Gowda, N.K., Antoniou, E., Ledoux, D.R. and Rottinghaus, G.E., 2009. Effects of turmeric (Curcuma longa) on the expression of hepatic genes associated with biotransformation, antioxidant, and immune systems in broiler chicks fed aflatoxin. Poultry Science 88: 2620-2627.

Yatim, A.M. and Sachan, D.S., 2001. Carnitine alters binding of aflatoxin to DNA and proteins in rat hepatocytes and cell-free systems. Journal of Nutrition 131: 1903-1908.

Yenilmez, A., Isikli, B., Aral, E., Degirmenci, I., Sutken, E. and Baycu, C., 2010. Antioxidant effects of melatonin and coenzyme Q10 on oxidative damage caused by single-dose ochratoxin A in rat kidney. Chinese Journal of Physiology 53: 310-317.

Young, I.S. and Woodside, J.V., 2001. Antioxidants in health and disease. Journal of Clinical Pathology 54: 176-186.

Yu, M.W., Zhang, Y.J., Blaner, W.S.and Santella, R.M., 1994. Influence of vitamins $\mathrm{A}, \mathrm{C}$, and $\mathrm{E}$ and beta-carotene on aflatoxin $\mathrm{B}_{1}$ binding to DNA in woodchuck hepatocytes. Cancer 73: 596-604.
Zbynovska, K., Petruška, P. and Capcarova, M., 2013. Effect of deoxynivalenol on some haematological, biochemical and antioxidant parameters of porcine blood in vitro. Journal of Microbiology, Biotechnology and Food Sciences 2: 1611-1628.

Zhang, B., Peng, X., Li, G., Xu, Y., Xia, X. and Wang, Q., 2015a. Oxidative stress is involved in patulin induced apoptosis in HEK 293 cells. Toxicon 94: 1-7.

Zhang, J., Zheng, N., Liu, J., Li, F.D., Li, S.L. and Wang, J.Q., 2015 b. Aflatoxin $B_{1}$ and aflatoxin $M_{1}$ induced cytotoxicity and DNA damage in differentiated and undifferentiated Caco- 2 cells. Food and Chemical Toxicology 83: 54-60.

Zhang, X., Jiang, L., Geng, C., Cao, J. and Zhong, L., 2009. The role of oxidative stress in deoxynivalenol-induced DNA damage in HepG2 cells. Toxicon 54: 513-518.

Zhang, Y., Han, J., Zhu, C.C., Tang, F., Cui, X.-S., Kim, N.-H. and Sun, S.-C., 2016. Exposure to HT-2 toxin causes oxidative stress induced apoptosis/autophagy in porcine oocytes. Scientific Reports 6: 33904.

Zhang, Y.F., Su, P.K., Wang, L.J., Zheng, H.Q., Bai, F.B., Li, P., Meng, X.P. and Yang, J.Y., 2018. T-2 toxin induces apoptosis via the baxdependent caspase- 3 activation in mouse primary Leydig cells. Toxicology Mechanisms and Methods 28: 23-28.

Zheng, J., Zhang, Y., Xu, W., Luo, Y., Hao, J., Shen, X.L., Yang, X., Li, X. and Huang, K., 2013. Zinc protects HepG2 cells against the oxidative damage and DNA damage induced by ochratoxin A. Toxicology and Applied Pharmacology 268: 123-131.

Zheng, Q.T., Yang, Z.H., Yu, L.Y., Ren, Y.Y., Huang, Q.X., Liu, Q., Ma, X.Y., Chen, Z.K., Wang, Z.B. and Zheng, X., 2017. Synthesis and antioxidant activity of curcumin analogs. Journal of Asian Natural Products Research 19: 489-503.

Zhong, Y., Jin, C., Gan, J., Wang, X., Shi, Z., Xia, X. and Peng, X., 2017. Apigenin attenuates patulin-induced apoptosis in HEK293 cells by modulating ROS-mediated mitochondrial dysfunction and caspase signal pathway. Toxicon 137: 106-113.

Zhou, X., Wang, Z., Chen, J., Wang, W., Song, D., Li, S., Yang, H., Xue, S. and Chen, C., 2014. Increased levels of IL-6, IL-1beta, and TNF-alpha in Kashin-Beck disease and rats induced by T-2 toxin and selenium deficiency. Rheumatology International 34: 995-1004.

Zhu, L., Zhang, B., Dai, Y., Li, H. and Xu, W., 2017. A review: epigenetic mechanism in ochratoxin A toxicity studies. Toxins 9: 113.

Zuo, L., Zhou, T., Pannell, B.K., Ziegler, A.C. and Best, T.M., 2015. Biological and physiological role of reactive oxygen species - the good, the bad and the ugly. Acta Physiologica 214: 329-348. 
